\title{
GEOLOGY AND MINERAL RESOURCES OF THE MANKHAMBOVSKY BLOCK (SUBPOLAR URALS)
}

\author{
Vladimir Aleksandrovich Dushin, \\ Vladimir.Dushin@m.ursmu.ru \\ Denis Igorevich Prokopchuk, \\ uva9090@mail.ru \\ Veniamin Sergeevich Koz'min, \\ Veniamin.Kozmin@m.ursmu.ru \\ Evgeniy Aleksandrovich Zhuklin, \\ Zhuklin7@gmail.com \\ Artem Konstantinovich Trutnev \\ tema.trutnev@yandex.ru
}

\author{
Ural State Mining University \\ Ekaterinburg, Russia
}

\begin{abstract}
Relevance of the work is in the fact that the studies of the last decade confirm good prospects of the Mankhambovsky block in relation to mineral resources. These include the research in connection with the work of the Northern Scientific-Research Geological Expedition (SNGEE) under the State Program "Reproduction and Use of Mineral Resources for 2012-2020". The territory considered in the paper is related to the mountainous, exposed part of the Northern and Nether-Polar Urals from the waterhead of the Pechora river in the south to the Manyi river-basin in the north and stretches in the meridional direction by almost $300 \mathrm{~km}$ including the Khanty-Mansiysk Autonomous Region - Yugra and partly - the Republic of Komi. The prospects of the Mankhambovsky block in relation to ore minerals are confirmed by studies of the last decade including some works of the Northern Scientific-Research Geological Expedition (SNGEE). More than 50 ore occurrences and about 200 mineralization points for ferrous, nonferrous, noble, radioactive and rare metal ores have been identified within the area under consideration. Iron-ore features are developed limitedly and accomplished by two ore formations - banded iron formations and skarn iron-ore one. Only copper is widely used among nonferrous metals although no significant concentrations are found, and other metals are practically not shown, with the exception of poor polymetallic mineralization in the beresitized sediments of the Laptopayskaya suite. A number of rare metals, including niobium, tantalum, beryllium, zirconium, and also rare-earth elements in complex with uranium and thorium are widely developed within the Mankhambovsky structure, with uranium and thorium leading in the ores. Radioactive elements in association with thorium, rare and rare earth metals are the leading minerals of the Mankhambovsky block. To date, there are about 20 objects of various sizes.

Purpose of this work is to determine the prospects of the Mankhambovsky block for rare-metal-uranium-thorium mineralization.

Results of the work. According to the conditions of formation and peculiarities of the placement of uranium-rare metal mineralization, three ore formations are distinguished: 1) uranium polygenic formation in unconformity zones localized in the frame of the Mankhambo block in terrigenous rocks of the base of the Hobeinskaya suite $\left(\mathrm{RF}_{3} h b\right) ; 2$ ) uranium berezitic formation - hydrothermal volcanogenic in the rhyolites of the Sablegorskaya and Riphean-Vendian Laptopayskaya suites; 3 ) formation of uranium-bearing peatlands - modern exogenous infiltration formation in mosses, peatlands and covering loams. The data obtained make it possible to assert that within the Mankhambovskiy block it is possible to expect the discovery of medium-scale deposits of multimetal ores.
\end{abstract}

Keywords: geology, black, non-ferrous, rare metals, uranium, thorium, Subpolar Urals, structural-formational zone, Mankhambovsky block, ore occurrences, isotopic age.

I ntroduction

Numerous researchers have been engaged in studying the geology and metallogeny of the Mankhambovsky block in different years beginning with A. N. Aleshkov (1937) and N. A. Sirin (1941). We should note some of them, M. B. Fishman, B. A. Goldin, E. P. Kalinin, S. S. Shcherbin (1963-1970), V. N. Malashevskiy (1970), V. S. Mityusheva (1971), G. I. Sevastyanov (1974). L. T. Beliakova (1968-1979), V. A. Dushin (1984-1987, 2006-2016), A. V. Kalinovsky (1989-1990) and others were dealt with the same issues during their geological surveys and thematic works.

The Mankhambovsky block is a large segment of the southern part of the Lyapinskaya structural-formational zone (megablock) of the Subpolar Urals (Fig. 1). It was proposed in previous works as an independent pre-Paleozoic Timaizsk transverse uplift [1], and then finally verified on the basis of geological and geophysical materials [2].

The Lyapinskiy megablock is a complex heterogeneous rock structure of various geodynamic environment $[3,4]$ realized in definite tectonic elements where the Paleocontinental, Paleoceanic, and Plate sectors are distinguished from the west to the east (Fig. 1). The first one includes some accretional constructive-destructive complexes of Pre-Uralide (Mankhambovsky, Malopatoksky, Nyartinsky, Nerkayusky blocks) and rift slope formations of the Paleozoic (Eletskaya and Lemvinskaya structural-formational zones), at the base of which fragments of the ancient Archaean-Proterozoic crust (with Sm-Nd age of 1.4-2.9 billion years), usually continental one (Nyartinsky, Nerkayusky, etc.). The second one documentarily known as the Tagilskaya synform (Tagilskaya structural-formational zone) includes structural and compositional complexes of the melanocratic base (Dzelyausky block) and island-collision zone terrains of the Early Middle Paleozoic [4, 5]. The last of these is blocked by typical platform sediments of the West Siberian plate which has a discordant occurrence, with the crust of weathering in the base, on the Paleozoic deposits $[1,6]$.

The oldest deposits, the basement of the Mankhambovskaya antiform (the Ukyu river, Pad-El) are represented by a variety of amphibolite, gneisses, migmatites, quartzites and crystalline schists. They are distinguished as part of the Nyartinskaya poorly defined formation, which has a visible thickness of more than $1500 \mathrm{~m}$. By analogy with the Nyartinsky complex, the age of garnet-biotite gneisses is determined on the basis of zircons isotope dating methods U-Pb (SHRIMP-II). It showed values of $2125 \pm$ 25 million years; $2210 \pm 25$ million years; muscovite-biotite gneiss with a garnet of $1950 \pm 35$ million years [6, 7]. The age of strata is difficult to be determined. However, the presence of Early Proterozoic isotopic clusters in younger complexes of this region, along with intense metamorphism of the garnet-amphibolite facies and the discordance of structures, allows them to be classified 


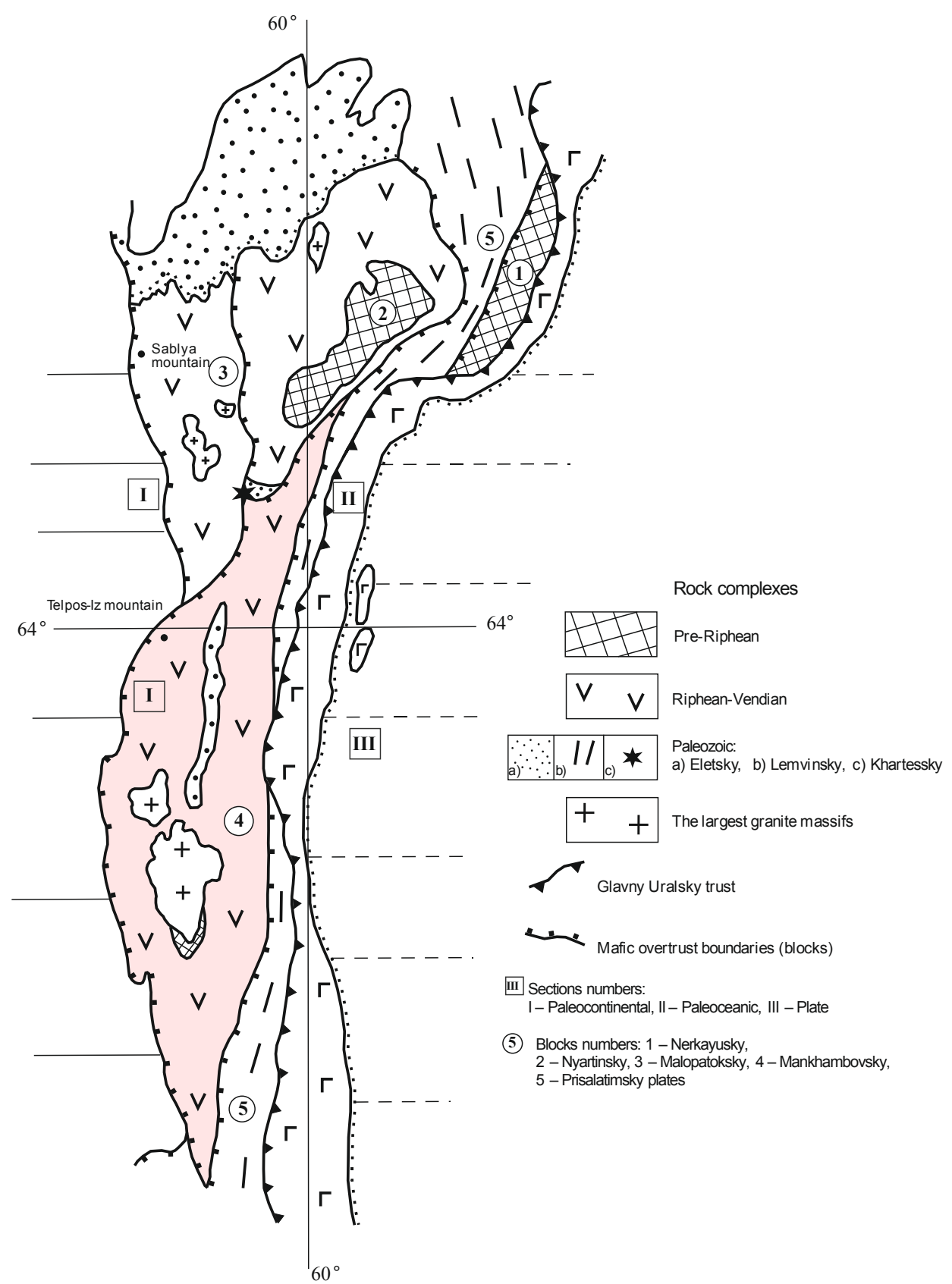

Figure 1. Tectonic classification plan of the Lyapinsky megablock.

Рисунок 1. Схема тектонического районирования Ляпинского мегаблока.

with the early Proterozoic with a certain degree of conditionality $[1,3,8]$. The Riphean-Cambrian deposits, which comprise $90 \%$ of the Mankhambovsky block, differ significantly from the other structures by composition of components, volume, and ratio of sedimentary and magmatic rocks (Fig. 2). They are metamorphosed under conditions of greenschist and less often amphibolite facies and are divided into a series of suites from the Early Riphean Mankhobeinskaya $\left(\mathrm{RF}_{1}\right)$, Shchokurinskaya $\left(\mathrm{RF}_{2}\right)$ to Vendian Laptopayskaya $\left(\mathrm{V}_{2}-\mathrm{E}\right)$, which are more or less characterized by paleontology. The total thickness of the sections is usually 4-8 thousand meters $[5,6]$.

The intrusive magmatism of this period is represented by the Mankhambovsky $\left(\mathrm{RF}_{2}\right)$ granite, sysinsky gabbro-diorite-granite $\left(\mathrm{RF}_{3}\right)$, Parnuksky diorite-gabbro $\left(\mathrm{RF}_{3}-\mathrm{V}_{1}\right)$, and Salnersky (Potemyusky) granite-leucogranite (V- $€$ ) complexes [6].

Paleozoic deposits are considered in two structural-formation zones of the Belsko-Eletskaya and Zilairo-Lemvinskaya zones characterized by facies-formation features of deposition of sediments with a characteristic complex of species composition of the fossil fauna. The sediments of the first zone are precipitates of the shelf type of Telpskaya $\left(\mathrm{O}_{1} t\right)$, Khydeiskaya $\left(\mathrm{O}_{2} h d\right)$, Shchugorskaya $\left(\mathrm{O}_{2-3} \check{s} \mathrm{c}\right)$ suites and Tabarotinskaya $\left(\mathrm{O}_{3}-\mathrm{S}_{1} t b\right)$ series in the Telpos-Iz-Mankhambo region. The Zilaro-Lemvinskaya zone is formed of deeper-water slope sediments of Saranhapnerskaya $\left(\Theta_{3}-\mathrm{O}_{1}\right)$, Khomassinskaya $\left(\mathrm{O}_{2}\right)$ and Pol'inskaya $\left(\mathrm{O}_{3}\right)$ suites within the Salatimskiy allochthon, which contacts with the complexes of the Tagilskaya megazone. The total thickness of sediments is more than 4 thousand meters in the Bielsko-Eletskaya zone and 2 thousand meters in the Zilairo-Lemvinskaya zone. The intrusive magmatism of the Paleozoic is manifested both in the Riphean-Vendian basement of the Lyapinskaya structural-formational zone (SFZ) - (Khartessky kimberlite $\left(\Theta_{3}\right)$, Siv'yaginsky ${ }^{\star 1}$ picrite $\left(\Theta_{3}\right)$, Malopatoksky doleritic $\left(\Theta_{3}\right)$, Paypudynsky ${ }^{\star}$ trachyrhyo- 

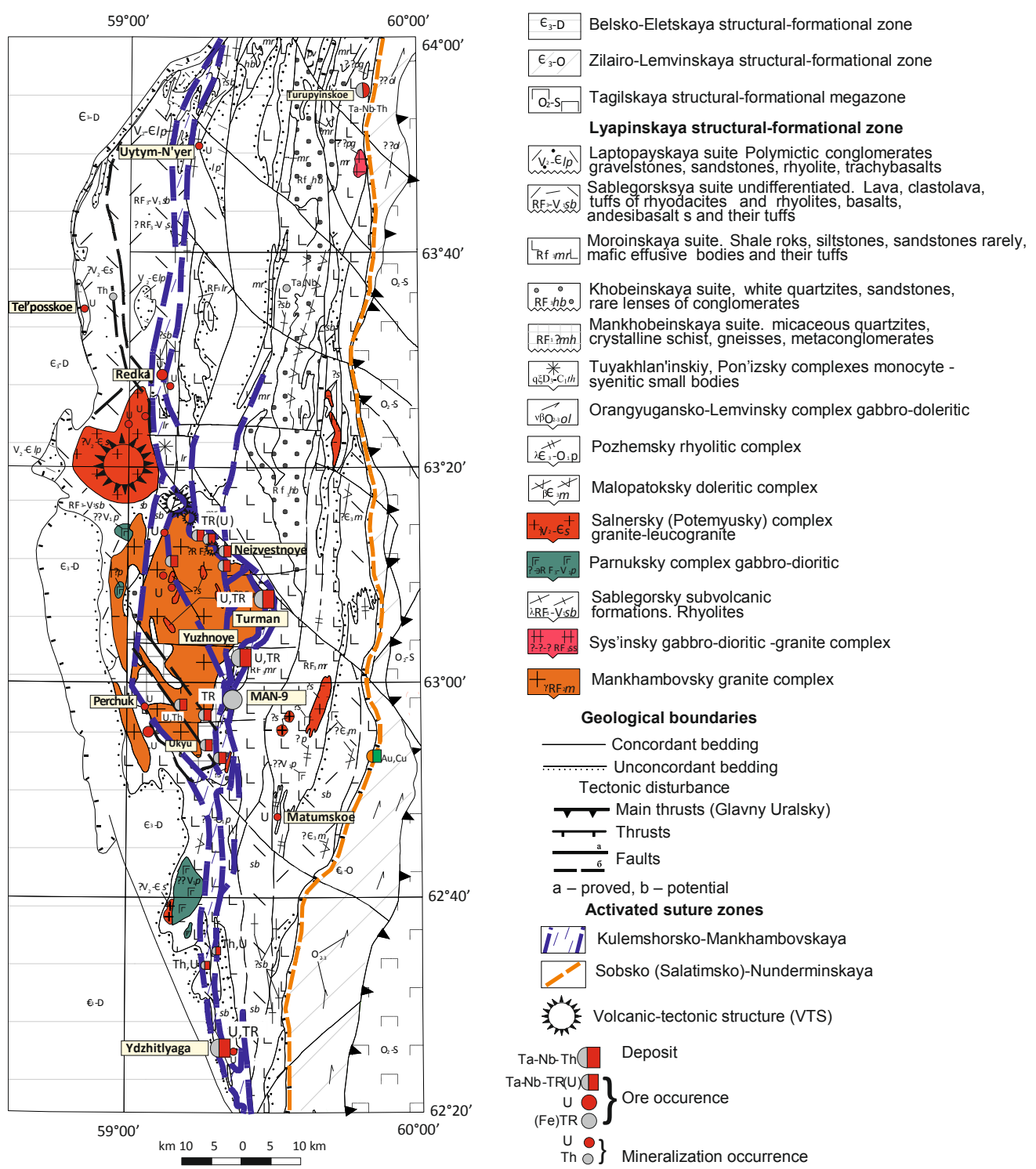

Figure 2. The geological map of the Mankhambovsky block (prepared by V. A. Dushin). Рисунок 2. Геологическая карта Маньхамбовского блока (составил В. А. Душин).

lite $(\mathrm{C}-\mathrm{O})$, Tuyakhlan'insky monzonite-syenitic $\left(\mathrm{D}_{3}-\mathrm{C}_{1}\right)$ complexes, as well as in the Paleozoic Belsko-Eletskaya (Lekvozhsky dolerite $\left(\mathrm{O}_{1}\right)$ complex) and Zilairo-Lemvinskaya (Pozhemsky rhyolitic $\left(\Theta_{3}-\mathrm{O}_{1}\right)$, Orangyugansko-Lemvinsky $\left(\mathrm{O}_{1-2}\right)$ complexes) structural-formational zones.

Mesozoic, more precisely Late Permian-Triassic magmatism is represented by small bodies and dykes of dolerites, trachydolerites, monzogabbros, monzosyenites and ultrapotassic rhyolites related to Yatyinsky*, Pon'izsky ${ }^{\star}$ and Bolshepatoksky ${ }^{\star}$ com- $^{*}$ plexes of plume nature activation type. As a rule, they are related to the northwestern structures of deep-level deposits and their branching structures, or traced the largest seams - Sobsko-Salatimskaya and Kulemshorsko-Mankhambovskaya zones, which largely determine ore saturation of the territory $[2,6,8]$.

More than 50 ore occurrences (manifestations) and about 200 mineralization points for ferrous, nonferrous, noble, radioactive and rare metal ores have been identified within the area under consideration.

Ferrous metals

Iron. In the Mankhambovsky block, iron ore objects are developed in a limited way and caused by the manifestations of two ore formations - banded iron formations (BIF) and skarn iron ore formation.

The formation of BIF is presented by a fairly large ore occurrence MAN-9, which is located in the upstream of the Mannjays river. It was opened in 1962 while carrying out of the airborne geophysical survey (Fig. 2).

It is associated with the zone of distant exocontact of the Mankhambovsky intrusion and is composed of metamorphic rocks of Nyartinsky complex $\mathrm{PR}_{1}$. The most common rocks are quartzites, quartzite sandstones, para- and ortho-amphibolites, crystalline (garnet) schists, gneisses (often diaphthorized ones), among which there are dykes of acidic and basic composition. "Shale rocks" contain impregnation and thin layers of magnetite. The distribution of magnetite aggregates is concordant or bedded, and their thickness varies from a few millimeters to $20-40 \mathrm{~cm}$. In some workings, subconcordant magnetite bodies with a thickness of

1 The map does not show them (Fig. 2) because of small dimensions. 


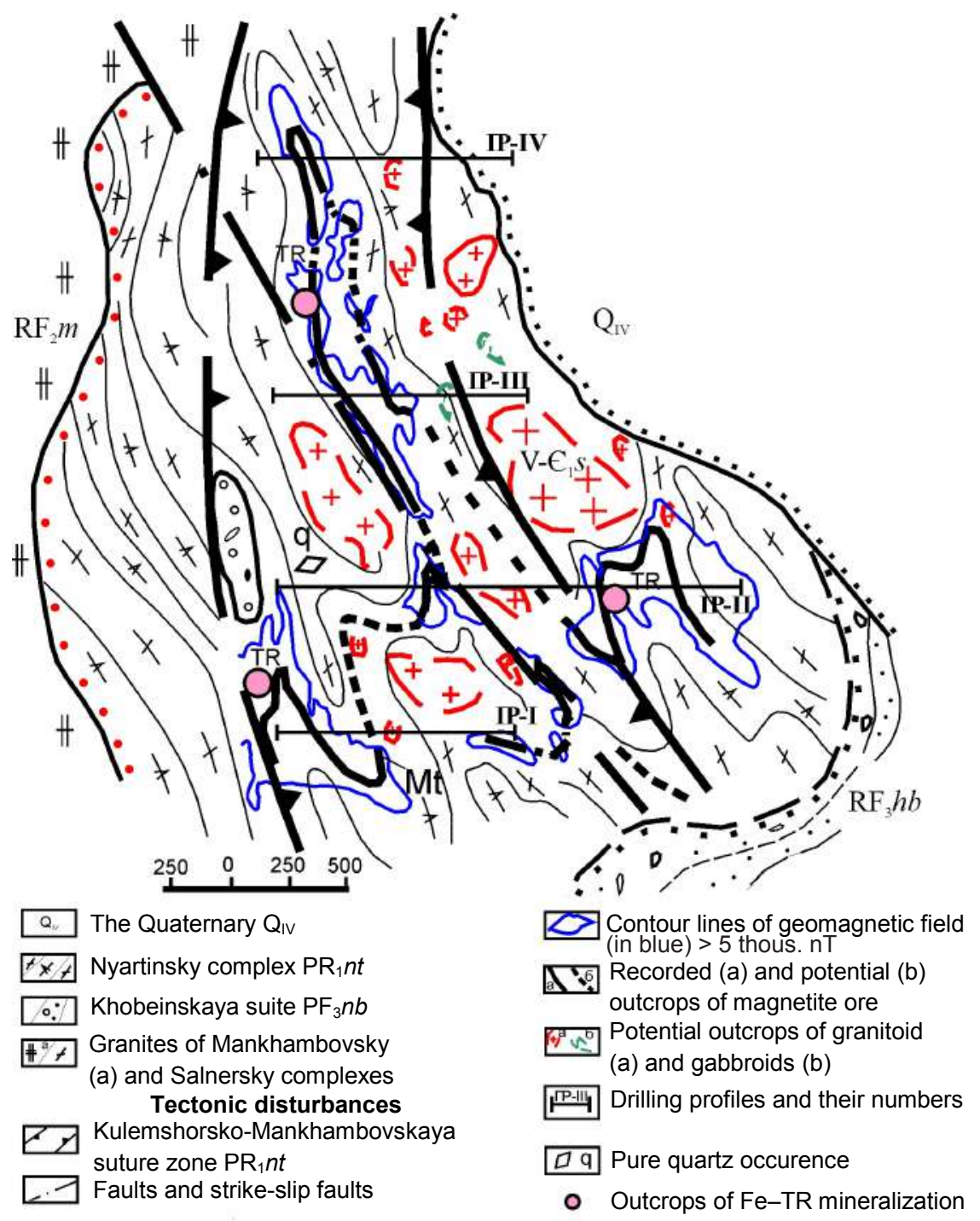

Figure 3. The essential structure (plan) of the productive horizon of Fe-quartzites (MAN-9).

Рисунок 3. Принципиальное строение (план) продуктивного горизонта Fe-кварцитов (MAH-9).

up to 4-5 $\mathrm{m}$ are found. The width of mineralized zones (ore bodies) in the ore manifestation reaches $30-40 \mathrm{~m}$. The size of grains of magnetite is from 0.007 to $0.2 \mathrm{~mm}$, and its content in ores varies from 15 to $70 \%$, whereas it does not exceed $10 \%$ in enclosing rocks. As a rule, ore bodies are localized in the hinge parts of folds of different order with faulting. They are medium and small in size lenticular deposits with uneven ore quality. The mineralized zones do not have clear geological boundaries; they are traced by positive magnetic anomalies stretching in the north-west direction with an intensity of $1000 \mathrm{nT}$ and higher. There are three of them most promising connected ore zones which are delineated. They have a length of 860 to $1160 \mathrm{~m}$ and a width of 24 to 620 $\mathrm{m}$. Zones were studied to the depth and to the area with the help of wildcat wells and gutters, according to which ore intervals of the average thickness of $2.43 \mathrm{~m}$ with a total iron content of $36.12 \%$ and a magnetite thickness of $23.09 \%$ were identified. The structural-lithological analysis of the yield of a productive bundle of ore-bearing quartzites allowed us to propose the existence of a single complex stratified ore horizon with a total length of more than $3 \mathrm{~km}$ (Fig. 3).

Magnetite ores and their enclosing rocks are characterized by the presence of impurities of non-ferrous, rare and noble metals. When carrying out the GDP-200/2 spectral analysis, an increased content (\%) is identified in most samples: W is $0.00007-$ 0.007 , Mo is $0.0005-0.01, \mathrm{Sn}$ is $0.001-0.02, \mathrm{Bi}$ is up to 0.005 , less often $\mathrm{Co}$ is $0.01-0.05, \mathrm{Cu}$ is $0.05-0,18$ (in some cases more than $1 \%), \mathrm{Ce}-0.01-0.1 ; \mathrm{Ag}$ - up to 1-2 ppm. Au content is determined to be $0.01-0.5 \mathrm{ppm}$ by atomic-absorption material analysis in some of samples scheelite (up to $22 \%$ of the weight of the heavy non-magnetic fraction), molybdenite, fluorite (up to $40 \%$ of the weight of the heavy non-magnetic fraction) were established by mineralogical analysis of protoplasm samples, along with pyrite and chalcopyrite that have already known. The mass-spectrometer analysis (ICP MS) of a sample from massive iron ores showed that the number of rare earths in the ore that mainly associated with orthite is $0.668 \%$ (Table 1 ). Some occasional fine (up to 0.1 $\mathrm{mm}$ ) grains of xenotime and monazite were also determined. In addition to pyrite and chalcopyrite, molybdenite and tetradymite have been also established. In two samples taken close the manifestation, Au was found in an amount of 0.2 and 0.5 ppm.

Points of iron mineralization of metamorphogenic type are recorded in the Riphean deposits along Podcherem, Ponya and Sale rivers, on the western slope of the Uitym-Niyer Ridge, along the eastern slope of the city of Miron-Vany-Nier and others. 
Table 1. Geochemical spectrum of massive iron ores of MAN-9 manifestation (sample - M-07k16), ICP MS, ppm.

Таблица 1. Геохимический спектр массивных железных руд проявления МАН-9 (проба М-07к16), ICP MS, г/т.

\begin{tabular}{cccccccccc}
\hline Element & Content & Element & Content & Element & Content & Element & Content & Element & Content \\
\hline $\mathbf{L i}$ & 7.4366 & $\mathbf{Z n}$ & 48.3 & $\mathbf{A g}$ & 0.1001 & $\mathbf{C e}$ & 225.3 & $\mathrm{Tm}$ & 1.5893 \\
$\mathbf{B e}$ & 1.7 & $\mathbf{G a}$ & 6.9 & $\mathbf{C d}$ & 0.1504 & $\mathbf{P r}$ & 26.5 & $\mathbf{Y b}$ & 9.6204 \\
$\mathbf{S c}$ & 14.7 & $\mathbf{G e}$ & 2.4078 & $\mathbf{I n}$ & 0.0514 & $\mathbf{N d}$ & 109.8 & $\mathbf{L u}$ & 1.3635 \\
$\mathbf{T i}$ & 1988.7 & $\mathbf{A s}$ & 0.1602 & $\mathbf{S n}$ & 7.4958 & $\mathbf{S m}$ & 23.7514 & $\mathbf{H f}$ & 1.8544 \\
$\mathbf{V}$ & 39.7 & $\mathbf{R b}$ & 52.4105 & $\mathbf{S b}$ & 0.1055 & $\mathbf{E u}$ & 1.4564 & $\mathbf{T a}$ & 1.0248 \\
$\mathbf{C r}$ & 11.5 & $\mathbf{S r}$ & 55.8 & $\mathbf{T e}$ & 0.0741 & $\mathbf{G d}$ & 24.3 & $\mathbf{W}$ & 1.6675 \\
$\mathbf{M n}$ & 669.4 & $\mathbf{Y}$ & 137.4 & $\mathbf{I}$ & 0.1746 & $\mathbf{T b}$ & 3.6731 & $\mathbf{R e}$ & 0.2045 \\
$\mathbf{C o}$ & 15.7 & $\mathbf{Z r}$ & 57.5 & $\mathbf{C s}$ & 0.6203 & $\mathbf{D y}$ & 21.1603 & $\mathbf{H g}$ & 0.0877 \\
$\mathbf{N i}$ & 11.3 & $\mathbf{N b}$ & 18.1 & $\mathbf{B a}$ & 232.4 & $\mathbf{H o}$ & 4.3309 & $\mathbf{T l}$ & 0.3247 \\
$\mathbf{C u}$ & 4.6 & $\mathbf{M o}$ & 2.0 & $\mathbf{L a}$ & 102.7 & $\mathbf{E r}$ & 11.2230 & $\mathbf{P b}$ & 4.71 \\
$\mathbf{B i}$ & 0.0993 & $\mathbf{T h}$ & 19.6154 & $\mathbf{U}$ & 5.1101 & & & & \\
\hline
\end{tabular}

Iron ore-skarn formation is represented by small objects in the rank of manifestations and points of mineralization. The largest of these is the manifestation of Pon'izskoye located in the interfluve of Ponja, Shchugor rivers near Pon'iz mountain. In the northern flank of the Pon'izskaya paleovolcanic structure within the intense aeromagnetic anomaly, we determined some outbreaks and sedentary debris of skarn-magnetite mineralization. From the surface, the dimensions of the outcrops of andradite skarns are the first tens of meters with the thickness of first meters. Mineral assemblage: magnetite, hematite; pyrite, galena, chalcopyrite are rarely observed. The iron content in the ores reaches $33 \%$; gold was identified up to 0.2 ppm by assay test [3, 5].

The scarn-magnetite mineralization is widely used within the block; its traces are noted in relation to the Sivyaginsky, Sablegorsk-Laptopaisky and Moroinsky magmatism.

Manganese. Manganese ore occurrences in the Mankhambovsky block have not yet been identified, although it contains the Early Vendian manganese-bearing level among the deposits of the Ar'yanshorskaya (Laptopaiskaya) suite, which contains carbonate-silicate ore deposits of the pebbled-aleurite-sand ore formation in the north of the Malopatoksky block (Nadezhdinsky ore deposit). In the described territory of the region of the Yany-Yankech Ridge, a submeridional band of 13 secondary local geochemical anomalies of manganese was identified with a content of $1-2 \%$ and a background of $0.05-0.1 \%$ within the productive Vendian level.

Non-ferrous metals

Only copper is widely used among nonferrous metals although no significant concentrations are found, and other metals are practically not shown, with the exception of poor polymetallic mineralization in the beresitized sediments of the Laptopaiskaya suite (Podgornoye).

Copper. Within the Mankhambovsky block, copper ore objects lie mostly in the rocks of the Sablegorskaya suite saturated with subvolcanic comagmatic rocks of basic and acidic composition. Mineralization of vein and stringer-porphyry mineralization, as a rule, are localized in metabasalts and controlled by small bodies and rhyolite dykes.

The most studied are the Taltminskoye and Rechnoye ore occurrences. Previous researchers considered them as cupper-sulfide ore occurrences. When performing GDP-200/2, we have not established typomorphic signs of sulfide ore mineralization and, with a certain degree of conventionality, copper objects of the south of Lyapinskaya structural-formational zone can be referred to a copper-quartz-sulphide ore formation [6].

Taltminskoye ore occurrence is located on the right bank of the Taltma river, $2.5 \mathrm{~km}$ below the outflow of the Tiltilma river. Sulphide mineralization was found during geological and geophysical works in 1967-1969.

The ore occurrence is composed of metavolcanogenic-terrigenous sediments of the Sablegorskaya suite, in which sericite-chlorite-albite-quartz schists participate in siltstone, less often in sandstones and in volcanics of acidic and basic composition. In shale rocks, carbonaceous material is often present in quantities of up to $5 \%$ or more. The shale rocks are intruded by small bodies of monzonites, diorites and alkali granosyenites $(\mu \xi)$ of the Manaragsko-Sivyaginsky complex $\left(\nu-\mu-\delta V_{1} m s\right)$. Wells intersected a stringer-porphyry fine-grained ore mineralization in apoteric shales of chlorite-carbonate-sericite (muscovite)-albite-quartz, quartz-albite-chlorite-sericite, carbon-quartz-carbonate-chlorite-albite-sericite composition. The ore-bearing zone is traced by boreholes and mine workings at $3000 \mathrm{~m}$ in the sub-meridional direction. Its width is up to $350 \mathrm{~m}$. The main ore minerals are chalcopyrite and pyrite. There is pyrrhotite sporadically. Sphalerite, galena, arsenopyrite are observed in occasional particles. In addition to sulphides, sphen is presented in the ore, and rutile is less common. The carbonic matter is evenly distributed over the rock in the form of small flakes. The content of $\mathrm{Cu}$ up to $0.73 \%, \mathrm{Zn}$ up to $0.15 \%, \mathrm{Ag}$ up to $9.75 \mathrm{ppm}$. In secondary dispersion halo of the object, the ore-bearing lithochemical anomaly with a content (\%) is outlined: $\mathrm{Cu} 0.004-0.006, \mathrm{Zn} 0.012-0.030$, Mo 0.0002-0.0005, Ba 0.04-0.06, Co 0.002-0.004 and Ag 0.2-1.0 ppm. According to our data, the wallrock alterations in enclosing rocks are closest to the processes of beresitization. The content of copper from the results of spectral approximate-quantitative analysis rarely exceeds $0.4 \%$. The atomic absorption analysis in the samples has shown Au content from 0.14 to 0.24 ppm.

Rechnoye mineralization is located in the middle reaches of the Yany-Manya river, $1 \mathrm{~km}$ east of the outflow of the Huntynya river. Sulphide mineralization here was found during the core drilling in 1967. Mineralization is located in the meta-terrigenous rocks of the Moroinskaya suite of the upper Riphean intruded by the Sablegorskaya subvolcanic formations of acidic and basic compositions. When carrying out the prognostic and exploration works in 2007-2009, several mineralized zones have been identified that are controlled by faults and localized at the contact of meta-terrigenous and meta-volcanic rocks. The length of the western zone is $2 \mathrm{~km}$, the eastern zone is $4 \mathrm{~km}$, the central zone is $1250 \mathrm{~m}$, the width of the zones is from 150 to $400 \mathrm{~m}$. The wells and ditches have revealed pyrite-carbonate-chlorite-micaceous metasomatites of the beresite formation with impregnation 
of sulfides. Together with pyrite, chalcopyrite, galena, sphalerite, and rarely chalcocite, bornite and barite in occasional particles are constantly present. Mineralization can be traced to a depth of $200 \mathrm{~m}$ or more. The content of $\mathrm{Cu}$ up to $0.9 \%, \mathrm{Zn}-\mathrm{up}$ to $0.9 \%$, $\mathrm{Ag}$ - up to $6.5 \mathrm{ppm}, \mathrm{Au}$ - up to $0.14 \mathrm{ppm}$. The spectral analysis of channel sampling from metasomatites showed the content (\%): $\mathrm{Pb}$ up to $0.18, \mathrm{Zn}$ up to 0.04 , Mo up to 0.001 , Ag up to $2 \mathrm{ppm}$; In addition, increased concentrations of Ce (up to $0.1 \%$ ) peculiar to acid effusives of the Sablegorskaya suites have been determined. Hematite, pyrite, ilmenite, chromespinelides, rutile, sphene, zircon, occasional particles of sphalerite, galena and gold are noted in the black sand taken from the areas of beresite oxidation. Against the background of the polymetallic assemblage of minerals, a group of rare earth and rare metal minerals, ortite and tantalum niobates, is manifested. According to the results of the atomic-absorption material analysis, the content of gold in the samples taken from the outbreaks of beresites manifestation was from 0.02 to $0.37 \mathrm{ppm}$.

Noble metals

Gold. A significant number of small gold ore objects (points of mineralization) is concentrated in the region of the fall of the Yangtump and Matum-Takhamtamya rivers to the Ioutynyu river. The largest of which is the manifestation of vein gold Yangtumpskoye. The Ioutyninskaya gold-bearing placer is located in the valley of the Ioutynya river - the largest one in the considered territory as a placer production.

The Yangtumpskoye manifestation is located in the left side of the valley of the Matum-Tahamtamya river, $1.5 \mathrm{~km}$ above its outflow. It is associated with the formation of the Sablygorskaya formation, represented by the apobasal shale rocks of chlorite-epidote, chlorite-feldspar-epidote, mica-chlorite-feldspar composition. Strike of the rocks is submeridional, strata inclination is eastern and heavy. The rocks are largely quartz bearing, carbonatized and epidotized. Some small sub-concordant dykes of gabbrodolerites are developed. The ore zone is represented by three stockwork-like bands, composed of quartz, carbonate-quartz veins, and stringers. The veins are associated with phyllites and phyllitic shale rocks occurring concordant to foliation and bearing a slight impregnation of bornite. The most interesting is the eastern belt, where a quartz vein with a thickness of up to $9 \mathrm{~m}$, traced at $50 \mathrm{~m}$, is opened with ditches. Strike of the vein is submeridional, strata inclination is eastern and heavy. The vein is associated with the contact of porphyritic andesibasalts and chlorite-feldspar-epidote shale rocks and oriented at $20-30^{\circ}$ on to the schistose. There is a dispersed impregnation of chalcopyrite and pyrite (up to 1\%); sometimes there are some runs up to $10 \mathrm{~cm}$ with a sulfide content of up to 40-50\%. Copper greens, malachite and azurite develop on the fissures and voids of rocks. According to the results of the chemical analysis of channel samples, the Au content is up to $0.2 \mathrm{ppm}, \mathrm{Cu}-\mathrm{up}$ to $0.48 \%$. Sericite-albite-quartz, sericite-chlorite-albite-quartz schistose metasomatites of silver-light gray color, with a thickness of 5 to $35 \mathrm{~m}$, penetrated by thin $(10-20 \mathrm{~cm})$ quartz veins, both concordant and counter ones. The gold content of one of the channel samples from the albic shale rocks according to the gold spectrometric analysis is $1 \mathrm{ppm}$, to the assay test $-0.4 \mathrm{ppm}$. Shale rocks differ somewhat increased radioactivity $(9-11 \mu \mathrm{R} / \mathrm{hr})$ from the surrounding rocks $(3-4 \mu \mathrm{R} / \mathrm{hr})$. The system of convergent counter feldspar-carbonate-quartz veins with a total thickness of about $1 \mathrm{~m}$ contains impregnation and schliers of chalcopyrite and pyrite. The gold content in the channel samples is $0.25-0.6 \mathrm{ppm}$ [3].

When verifying the points of mineralization of gold and copper in the middle reaches of the Matum-Tahamtamya river the metasomatic zoning of the enclosing rocks was studied. It shows that mineralization is connected with rocks of the formation of quartz-sericite metasomatites formed from propylitized metabasalts. Some mineragraphic studies have established the presence of hematite, chalcocite, chalcopyrite in ore-bearing metasomatites; covellite, bornite, pyrite, native copper have been established by mineralogical analysis of the crushed sample. There is also one grain of gold.

The increased gold content is characteristic not only of the metabasalts but the metarhyolites of the Sablegorskaya formation as well. In the drill-hole cores drilled by the Berezovskoye exploring-and-producing enterprise in the area of Yatya, there are some thin quartz, quartz-carbonate veins, and stringers with bornite and chalcopyrite in the metarhyolites, as well as feldspar-quartz veins with galena. An increased gold content in veins was established by atomic-absorption material analysis $-0.13,0.17$ and 0.086 ppm [6].

Another group of convergent gold ore and copper-polymetallic features is in the wellhead part of the Pazypatymsos stream, the left-bank tributary of the Iotynya river. Detailed works in this area called Pazypatymsos were also conducted in 1976-1981. We established the point of mineralization of gold within the boundaries of the section of ore occurrence of banded iron formations MAN-9. In the drill-hole cores C-68 drilled by the Berezovskoye exploring-and-producing enterprise, thin conformable counter sulfidized quartz veins and stringers have been established in magnetite mineralization of muscovite-quartz crystalline schists. Sulphides are represented by pyrite, chalcopyrite; molybdenite and tetrahedrite are noted in a subordinate quantity. We have established by spectral analysis the following: $\mathrm{Cu}-1 \%$; $\mathrm{Zn}-0.04 \%$; $\mathrm{Mo}-0.001 \%$; Bi $-0.005 \%$; $-0.003 \% ; \mathrm{Ag}-0.0002 \%$. The gold content, according to the results of the atomic-absorption material analysis, is $0.5 \mathrm{ppm}$; according to the assay test $-0.2 \mathrm{ppm}$. Apparently, the considered features of gold ore and copper-polymetallic mineralization belong to a single gold-sulphide-quartz vein formation.

The complex uranium mineralization of the eastern structure of the Mankhambo complex is characterized by a fairly high gold content, which confirms the point of view of S. S. Shcherbin about the prospects of conglomerates in relation to gold [9]. Thus, according to our data, in the sample of cement from conglomerates of Neizvestnoye ore occurrences, the content of noble metals is: $\mathrm{Au}-6.06 \mathrm{ppm}$; $\mathrm{Ag}-20.04 \mathrm{ppm}$ with a content of $\mathrm{U}-0.12 \%$; Th $-1.30 \%$; Bi $-180 \mathrm{ppm}$; $\mathrm{Nb}-0.26 \%$; Ta $-0.018 \%$; $\mathrm{Zr}$ $-0.7 \%$; Ce - 0,187 \%; Y - 0.059 \%; La - $0.18 \%$; $\Sigma \mathrm{TR}-0,8 \%$. In the course of works on studying the manifestations of uranium mineralization, some employees of OAO "UGSE" also established gold in the amount of up to 4.9 ppm in individual samples from uranium-bearing conglomerates and gravels of the areas of Turman, Paryaur, and Neizvestny [6, 10].

Silver. Elevated concentrations of silver (up to $10 \mathrm{ppm}$ ) are noted in quartz veins in the Yangtump area and in the zones of sulfide mineralization of the Ioutynya copper occurrence, as well as in a number of mineralization points of gold in the upstream of the Matum-Takhamtamya river. According to the results of the mineralogical analysis of the crushed sample from the quartz vein, there are some iron-silver-copper formations - isometric grains or close to them with pseudohexagonal outlines resembling the shape of pyrite crystals (pentagonal dodecahedron with a cube). Their size is $0.2-0.6 \mathrm{~mm}$. We have established by spectral analysis the following elements: basic - Cu, Ag, Fe; impurities - Zn, Mn, Cd, Al, Ba, Ca, Mg, Si. 
A high content of silver was established in complex uranium ore of the ore occurrence of Turman and the Paleodolinny area (manifestations of Paryaur and Neizvestnoye). Thus, in the trough-like structures of the first area and in the shallow-dipping ore zones of the second one, there is the presence of silver in the amount of 0.5 to $190 \mathrm{ppm}$ according to X-ray spectroscopic analysis of core samples. The mineralogical analysis of ores includes argentite and proustite.

Platinum. Platinum together with gold is found in alluvial placers of the main rivers and their tributaries. The average gradation factor is $0.365 \mathrm{~mm}$. In the Ioutyninskaya placer of the Pazypatymsosky area, platinum is contained in an amount of $1.4 \%$ of the total amount with gold. Its color is usually steel-gray with thin flake and lumpy form; rounding is mostly good. It is represented by palladic platinum and osmiridium, as far as the content of impurities is concerned (according to the spectral analysis).

The high content of platinoids in uranium ores was first established by our investigations. According to the results of the quantitative analysis (ICP MS), using the cement of ore conglomerates (radioactivity is $800 \mu \mathrm{R} / \mathrm{h}$ ) of Neizvestnoye manifestations with a content of $\mathrm{U}-0.12 \%$ and $\mathrm{Th}-1.30 \%$, the content of platinum group metal (PGM) was: Pt - 8.44 ppm, Ir - 5.11 ppm [6]. Close concentrations of platinum group metals were established during the prognostic and exploration works of OAO "UGSE" in the Verkhnetolinskaya area. In complex uranium ores of the Turman and the Paleodolinny area (manifestations of Paryaur, Neizvestnoye), the content of platinum group metals was: Ir - from 4.6 to 40 , Os - from 1.5 to $29 \mathrm{ppm}$, Ru - from 1-2 to 50-123 ppm, Ro - from 1.3 to $2.5-10 \mathrm{~g} / \mathrm{t}$. Pt - up to $13 \mathrm{ppm}$ is rarer in the ores $[2,6,10]$.

Rare metals, traced and rare-earth elements

Rare metals including niobium, tantalum, beryllium, zirconium, and rare-earth elements in complex with uranium and thorium are widely developed within the Mankhambovskaya structure and are represented by ore occurrences Neizvestnoye, Paryaur, Yuzhnoye, Ukyu, Bolshaya Turupya, and others.

Tantalum, niobium. The largest feature of these metals is the ore occurrence Bolshaya Turupya located in the interstream area of the Turupya and Tujahlanya rivers. The pay streak is about $650 \mathrm{~m}$ wide extends in the meridional direction by more than $6 \mathrm{~km}$. It was revealed by the polar airplane of the Shabrovskaya expedition in 1955 based on the results of the radiometric survey. It consists of three anomalies associated with the Sobsko-Salatimskaya activated suture zone (Fig. 2), along which narrow tectonic plates of Paleozoic rocks were formed. Radioactive anomalies and secondary dispersion halos (Be, Sn, Nb - $0.01 \%$, Y - $0.02 \%$, $\mathrm{Z}-0.1 \%$ ) trace the zones of alkaline metasomatites with columbite, pyrochlore, bastnasite, orthite, zircon, genthelvite, euclase, phenacite, fluorite (grain size is $0.07-1.2 \mathrm{~mm}$ ), and alkaline-carbonate metasomatites with apatite and fluorite. The age of muscovite from rare-metal micaceous metasomatites was determined from the K-Ar isochronopach at 330-320 Ma, which corresponds to the Middle Carboniferous period, and the age of the carbonate metasomatism - Medium-Late Triassic epoch [11]. The manifestation revealed seven sheet-like bodies localized in the cores of anticlinal folds of high orders. Mineralization is bedded on intensely altered mica-feldspar-quartz schists (metariolites).

When carrying out GDP-200/2, some mineralogical-geochemical features were studied in detail (P. L. Burmako, A. A. Bakilina). These are the features of manifestations of the Bolshaya Turupya, the wallrock metasomatites of which correspond to the eisite and qualmite formations [2].

The former is characterized by the formation at late stages of development of folded areas in the zones of deep faults, in felsic rocks and intermediate acidity rocks. Their formation is expressed by the wide development of processes of albitization, carbonatization, and chloritization. Ore minerals occur in the form of fine impregnations and micro-stringers. A characteristic sign of eisitization is the appearance of brownish-red coloration of rocks, due to the presence of finely dispersed hematite and uranium mineralization, and in the intermediate zones - apple-green, associated with hydromica formation. The development of processes of apatite mineralization and fluorsparization is typical for intermediate zones.

At the same time, crystallization of tantalumniobates requires higher temperatures. The occurrence of higher-temperature processes preceding the eisitization is indicated by the presence of a long-prismatic zircon predominated in the rocks of the inner zone. Due to a combination of all mineralogical and geochemical data, the early metasomatites preceding the eisites are referred to the quartz-albite-microcline (qualmite) metasomatic formation. It is with this formation that rare metal ore mineralization is associated. The following facts serve as signs of qualmites. In all metasomatic zones, the presence of relics of microcline, which is replaced by albite, was established. Sericitization of sodium-calcium feldspar is widely developed with the formation of deuterogenic soda feldspar. Impregnation of columbite is associated with chlorite-sericite and quartz-albite packs and is located evenly in them. For the rocks of the intermediate zone, a characteristic addition of $\mathrm{K}, \mathrm{Mg}, \mathrm{Ca}, \mathrm{Al}$ and $\mathrm{H}$ atoms is established, for the inner zone, $\mathrm{Mn}, \mathrm{Na}, \mathrm{Fe}^{3}$ and $\mathrm{Ca}$ are introduced. The geochemical specialization focused on rare metals ( $\left.\mathrm{Ta}, \mathrm{Nb}, \mathrm{Zr}, \mathrm{Sn}, \mathrm{Be}\right)$, as well as typical high-temperature minerals indicate the presence of qualmite formation. In determining the correlation dependence, a significant relation was established between the main ore elements - Nb, Zr, Sn, Be, Pb, Zn. The structural position of quartz-albite-microcline metasomatites is determined by their localization in the zones of large regional faults of the crystalline basement without an apparent connection with specific magmatic bodies.

Macroscopically ore-bearing rocks differ from the barren rocks only by increased radioactivity. In polished sections, impregnation of magnetite and sulfides, which form linear aggregates, are most often observed. Occasionally, columbite is found in the form of dark gray granules of tabular, cubic or curved shape, with an average size of $0.3 \times 0.5 \mathrm{~mm}$. The mineralogical analysis of crashed samples showed that the main mass of light fractions of concentrates are veined minerals: albite, muscovite, quartz, carbonate. Heavy fractions are represented by chlorite, apatite, fluorite, tourmaline. It is established in a subordinate amount: barite, zircon, leucoxene, monoclinic pyroxene, olivine. The following elements from ore minerals are present: pyrite, sphalerite, iron hydroxides, hematite, magnetite. Rutile, ilmenite, chalcopyrite, galena, molybdenite, cassiterite, native copper were noted in occasional particles. Minerals of tantalum and niobium were not found in crashed samples by mineralogical analysis in metasomatites. However, there are some microscopic inclusions in the sericite grains; they correspond to the properties of the tantalite-columbite group mineral. It should be noted that beryllium is found in the ore concentration of Turupyinsky mineralization in industrial concentrations; its concentration reaches $0.079 \%$. Mineralogically, it is represented by genthelvite, phenacite and euclase $[2,12]$. 
Regarding the mineragenic type of tantalum-niobium mineralization, there is no single point of view. S. G. Karachentsev and E. G. Negurica considered the Turupyinsky metasomatites as rare metal albitites comparing them with the Polar Urals ones (Taikeuskoye). A. V. Kalinovsky identifies alkaline metasomatites - albitites and alkaline-carbonate -carbonatites? and, taking into account their connection with the Turupyinskaya ring structure, considers the mineralization to be closer to carbonatites with the features of both groups of formations. According to the latest published data [12-14], isotope-geochemical (Rb-Sr, $\mathrm{Sm}-\mathrm{Nd}$ ) and geochemical (REE, Ba, Sr, etc.) studies of rocks as well as microprobe analyzes of ores unambiguously reject the carbonatite nature of metasomatites and indicate on the connection of the mineralized zones of the Turupyinsky manifestation with albitized and sericitic schists (metariolites), and not with carbonate rocks. On the basis of these materials, as well as the results of our own research given above in the description of ore manifestation, rare metal mineralization refers to a rare-earth-rare metal uranium-containing formation in alkaline metasomatites [2]. They are close to the rare metal object described above but smaller in importance (not studied); they are established in several places within the Mankhambovsky block and are mainly associated with dykes and small bodies of trachyriolites and granosyenites. The latter intrude the Riphean-Vendian section and are accompanied by metasomatites of the qualmite and sodic alteration formations. In the region of outflows of the Watla, Taltma, Tolia, Yatya rivers, the tributaries of the Ponya, Huntynya, Nyartsyuyu rivers and others (Table 2). The rare-metal-rare-earth mineralization in connection with the apogranities is manifested only within Mankhambovsky and Ilyaizsky massifs, the ore-bearing magma complex of which is the Salnersky granite-leucogranite complex of the Vendian-Early Cambrian. The characteristics of the objects are given in Table 3.

Radioactive elements

Uranium, thorium. Uranium, in association with thorium, rare and rare-earth metals, is the leading mineral in the Mankhambovsky block; about 20 its objects of different sizes are established here (Fig. 2).

Table 2. Characteristics of ore objects in connection with small bodies of trachyriolites.

Таблица 2. Характеристика рудных объектов в связи с малыми телами трахириолитов.

$\begin{array}{cc}\text { Name of the object } \quad \begin{array}{c}\text { Ore-hosting rocks, complex, } \\ \text { metasomatites }\end{array} & \begin{array}{c}\text { The content of ore elements, \%; } \\ \text { radioactivity, } \mu \mathrm{R} / \mathrm{hr}\end{array}\end{array}$

Rare-earth-rare metal alkaline metasomatites formation

Area Nyatrsyuyu

(western, eastern)

Nyartsyuyu II

Verkhnetaltminskoe

Huntynya

The source of the

Bol. Turupya

Vatlinskoe
Trachyriolites; Ponyizsky

Quartz porphyry; Laptopaysky

Riolites, trachyriolites, (qualmites?); Sabegorsky

Riolites, trachyriolites (qualmites); Laptopaysky

Granosyenites, rhyolites (qualmites); Ponyizsky

Rhyolites, qualmites; Ponyizsky
$\Sigma T R-0,01-0,06$ to $0,1-0,25$; $\mathrm{Ta}_{2} \mathrm{O}_{5}-0.005$

$\mathrm{Nb}_{2} \mathrm{O}_{5}-0.001$ to $0.018 ; \Sigma T R$ $-0.002-0.007$ to 0.02 chemical analysis $0.002-0.006$ to $0.2 ; \mathrm{U}-0.001$

$\mathrm{Nb}-0.01 ; \mathrm{Ta}$ v 0.0014; $\mathrm{Zr}-0.03$; U - 8 ppm; Th-30 ppm

$\mathrm{Nb}-0.05 ; \mathrm{Ce}-0.02 ; \mathrm{Y}-0.006 ; \mathrm{Zr} \quad$ Xenotime, tantalo-niobates, euxenite, $-0.1 ; \mathrm{Ba}-0.9 ; \mathrm{Au}-0.16-0.33 \mathrm{ppm}$ polycrase, hematite, zircon, pyrochlore, monazite, chalcopyrite

Ta - 0.001; Ce - 0.01; Sn - 0.002; Pyrochlore, zircon, fersmite, chevkinite $\mathrm{Pb}-0.01 ; \mathrm{Au}-8 \mathrm{ppm}$;

$\mathrm{Nb}_{2} \mathrm{O}_{5}-0.01 ; \mathrm{Y}-0.024 ; \mathrm{Ta}_{2} \mathrm{O}_{5}-$ Tantalo-niobates, fluorite 0.003

Table 3. Characteristics of ore objects of the endo-exocontact part of the Mankhambo massif.

Таблица 3. Характеристика рудных объектов эндо-экзоконтактовой части массива Маньхамбо.

\begin{tabular}{|c|c|c|c|}
\hline Name of the object & $\begin{array}{l}\text { Ore-hosting rocks, formation, } \\
\text { complex }\end{array}$ & $\begin{array}{l}\text { The content of ore elements, \%; } \\
\text { radioactivity }\end{array}$ & The main minerals of ores \\
\hline \multicolumn{4}{|c|}{ Rare-earth-rare metal uranium-bearing apogranite formation } \\
\hline Shchugorskoye & Granites (albitites), Salnersky & $\begin{array}{c}\mathrm{Ta}_{2} \mathrm{O}_{5}-0.005, \mathrm{Nb}_{2} \mathrm{O}_{5}-0.01-0.12 \\
60 \mu \mathrm{R} / \mathrm{hr}\end{array}$ & Orthite, zircon, fluorite, apatite, hematite \\
\hline Tol'ya & $\begin{array}{l}\text { Cataclased granites, } \\
\text { greisenization,Salnersky }\end{array}$ & $\begin{array}{c}\mathrm{Ta}_{2} \mathrm{O}_{5}-0.005-0.01, \mathrm{Nb}_{2} \mathrm{O}_{5}- \\
0.005-0.02, \Sigma \mathrm{TR}_{2} \mathrm{O}_{3} \text { up to } 0.005 \\
60 \mu \mathrm{R} / \mathrm{hr}\end{array}$ & Orthite, zircon, fluorite, apatite, hematite \\
\hline Zapadnoye & $\begin{array}{l}\text { Cataclased granites, } \\
\text { greisenization, Salnersky }\end{array}$ & $\begin{array}{l}\mathrm{Ta}_{2} \mathrm{O}_{5}-0.003, \mathrm{Nb}_{2} \mathrm{O}_{5}-0.009 \\
\Sigma \mathrm{TR}_{2} \mathrm{O}_{3} \text { up to } 0.05 ; 50 \mu \mathrm{R} / \mathrm{hr}\end{array}$ & Orthite, zircon, fluorite \\
\hline Shchugorskoye II & $\begin{array}{l}\text { Leucocratic cataclased } \\
\text { granites, albitization, } \\
\text { greysenization, Salnersky }\end{array}$ & $\begin{array}{l}\mathrm{U}=0.019-0.076, \mathrm{Th}=0.376-1.5 \\
\text { Th } / \mathrm{U}-20 ; 760-1530 \mu \mathrm{R} / \mathrm{hr}\end{array}$ & $\begin{array}{l}\text { Fluorite, thorite, orthite, monazite, zircon, } \\
\text { hematite, U-containing magnetite, molyb- } \\
\text { denite, fergusonite, sphen }\end{array}$ \\
\hline $\begin{array}{l}\text { Otverzhennoye } \\
\text { (Tur'inskoye) }\end{array}$ & $\begin{array}{l}\text { Granite-porphyry cataclased, } \\
\text { beresitization. Salnersky }\end{array}$ & $\begin{array}{l}\mathrm{U}=0.082-0.129, \mathrm{Ti} \text { to } 1.0, \mathrm{~Pb} \\
\text { to } 0.01, \mathrm{Zn} \text { to } 0.02, \mathrm{Mn} \text { to } 0.18, \mathrm{Hf} \\
\text { to } 0.02 ; 200-1000 \mu \mathrm{R} / \mathrm{hr}\end{array}$ & Uranotorite, fluorite, galena, monazite, sphen \\
\hline Pon'izskoe I & $\begin{array}{l}\text { Leucogranites, albitites, } \\
\text { beresites }\end{array}$ & $\begin{array}{c}Y-0.05 ; \mathrm{Zr}-0.08 ; \mathrm{Ce}-0.01 \\
\mathrm{Au}-0.05 \text { ppm }\end{array}$ & $\begin{array}{l}\text { Xenotime, orthite, zircon, fluorite, sphen, } \\
\text { octahedrite, tourmaline }\end{array}$ \\
\hline
\end{tabular}


According to the conditions of formation and peculiarities of uranium-rare metal mineralization, three ore formations are distinguished: 1) uranium polygenic formation in unconformity zones localized in the frame of the Mankhambo block in terrigenous rocks of the base of the Hobeinskaya suite $\left.\left(\mathrm{RF}_{3} h b\right) ; 2\right)$ uranium berezitic formation - hydrothermal volcanogenic in the rhyolites of the Sablegorskaya and Riphean-Vendian Laptopayskaya suites; 3) formation of uranium-bearing peatlands - modern exogenous infiltration formation in mosses, peatlands and covering loams [2].

Uranium-rare metal objects are distributed unevenly across the territory. Most of them (Neizvestnoye, Paryaur, Severnoye, Turman, Yuznoye) are associated with the eastern exocontact of the Mankhambovsky granite massif. The other group is located in the southern near-contact zone (Khapkhartuitump, Ukyu, Zapadnoye, Yuzhnoye II). The uranium group (Perchuk I, II, Mokhovoye I, II, Maldizskoye) was found in the remote endocontact and inside the massif (surface type). The uranium beresite group is located in the north (Redka I, II) and in the south (Matumskoye) from the Mankhambovsky pluton within the unified Kulemshorsko-Mankhambovskaya suture zone, which is an activated area of structural-stratigraphic unconformity (SSU) identified by us $[2,6]$, as well as tracing uranium, uranium-rare metal, uranium-rare earth-rare metal mineralization within the Lyapinsky megablock.

The northern part of the ore zone is located in the upstream of the Shchugor and Tolya rivers and includes ore occurrences and mineralization points of the Neizvestnoye, Paryaur and Severny. Neizvestnoye and Paryaur occurrences have been studied in the process of prognostic and exploration works for uranium in 2007-2009 within the boundaries of the detailed Paleodolinny section.

Neizvestnoye occurrence is in the sources of the Parya river on the eastern slope of Tol'ya-Atol'yasyahal (Fig. 4). The horizon of conglomerates, breccia-conglomerate and quartzite sandstones of the Hobeinskaya suite ( $\left.\mathrm{RF}_{3}\right)$ lies at the base of the section of the ore-bearing stratum with a thickness of 3-10 m, in the section of which there are concordant mylonitization zone and cataclasis with a thickness of 5-15 $\mathrm{m}$ and bedding. According to gamma ray logging data, the zone of anomalous radioactivity $(100-2800 \mu \mathrm{R} / \mathrm{hr})$ is fixed at the contact of the unconformity of rocks and at the base of the section among brecciated conglomerates, conglomerate breccias and quartzite sandstones. The thickness of the zone is from 1 to $6 \mathrm{~m}$. Silica-alkaline rock alterations are spatially associated with the ore zone including silicification, carbonatization, pyritization, chloritization and epigenetic oxidation. At depths of 40-90 m, from one to three converged ore intervals are established into the ore deposit Severnaya II with a content of U $0.014-0.069 \%$ for thickness from 0.5 to $1.6 \mathrm{~m}$, Th $-0.13-0.41 \%$ at $\mathrm{Th} / \mathrm{U} 3.5-10.3$. There are uranium-containing thorite-orangite, zircon, orthite, rutile, sphen, etc. in the ores composition. The dip of the ore zones to the northeast at $30^{\circ}-40^{\circ}$. The potential width of the ore deposit of Severnaya II to a depth of $300 \mathrm{~m}$ is about $500 \mathrm{~m}$, the length is more than $2.5 \mathrm{~km}$ [2, 10].

Paryaur manifestation is located in the upstream of the left tributary of the Parya river at the $586.2 \mathrm{~m}$ elevation. An anomalous band of $1.4 \mathrm{~km}$ in length is established in exocontact of the granite massif of Mankhambo and is outlined by pits, ditches and verified by the profiles of wildcat wells. Two narrower (with a width of 50-50 m) anomalous zones are outlined by ditches to the south in endocontact of granites. The thickness of the deposits is $1-50 \mathrm{~m}$, the radioactivity is $50-500 \mu \mathrm{R} / \mathrm{hr}$. Composition of ores: magnetite, uranium-containing zircon, thorite, sphen, fluorite, titanic iron ore, rutile, tourmaline. The content of $U$ is $0.01-0.02 \%$, $\mathrm{Th}$ is $0.06-1.2 \%, \mathrm{Th} / \mathrm{U}$ is $3-6$ [10]. Three sheet-like ore bodies are distinguished in the section. The first (lower) is outlined by a dip of $300 \mathrm{~m}$ to a depth of $160 \mathrm{~m}$ and is associated with the horizon of brecciated gravelite quartzite sandstones with a thickness of 2-4 m. The content of U $0.01-0.032 \%$ (mean $0.024 \%$ ), Th $-0.04-0.19 \%$ (mean $0.139 \%$ ) for thickness from 0.5 to $6.9 \mathrm{~m}$ (average $2.5 \mathrm{~m}$ ) at $\mathrm{Th} / \mathrm{U}$ about 6 . The other two (middle and upper ones) are associated with the horizons of brecciated gravelly quartzite sandstones in the depth intervals of 56-78 and 125-145 $\mathrm{m}$. The average content of uranium in them is $0.018-0.017 \%$, Th is $0.1-0.14 \%$ for thickness of $1.1-0.3 \mathrm{~m}$, respectively. The occurrence of ore bodies is shallow $\left(25^{\circ}-35^{\circ}\right)$. Both bodies united in the ore deposit Severnaya I, are accompanied by the manifestation of high-temperature siliceous-alkaline metasomatic changes (silicification, K-feldsparization, albitization, fluorsparization, hematitization, etc.) developing from the granite basement to the lower part of the ore-bearing pack of gravelly quartzite sandstones. The processes of low-temperature hydrothermal changes (silicification, carbonatization, chloritization with bornite, chalcopyrite, molybdenite) are manifested in the upper part of the section of the ore-bearing strata and along the overlying shale rocks. These processes are also noted in the lower part of the section of the ore-bearing strata near the contacts of the bedded dolerite dyke, where large (up to $2-3 \mathrm{~cm}$ ) pockety segregations of molybdenite, chalcopyrite, platy hematite are fixed.

The western part of the lateral ore reserves is represented by a series of converged ore bodies shallow dipping $\left(20^{\circ}\right)$ at a depth of 15 to $50 \mathrm{~m}$. They are localized in the fault zone at the base of section of the gravelly quartzite sandstones and are accompanied by siliceous-alkaline rock alterations with the addition of potassium. The content of $\mathrm{U}$ is $0.01-0.032 \%$ for thickness of $0.5-3.4 \mathrm{~m}$ with a content of Th $0.03-0.11 \%$ and Th/U of 3-3.4. To the west, near the large sub-meridional fault, the thickness of the ore deposit increases to $22-30 \mathrm{~m}$, the content of $\mathrm{U}$, according to the data of channel sampling, is $0.015-0.02 \%$ at thickness of $0.5 \mathrm{~m}$ and concentration of Th $0.07-0.12 \%$ and $\mathrm{Th} / \mathrm{U} \sim 6$. On the western pinch, the ore deposit is outlined on the strike along a high-dipping tectonic disturbance to the north at $1.100 \mathrm{~m}$. It is associated with the brecciation zone developed at the base of the horizon of gravelly quartzite sandstones. The thickness of ore deposit is $5-10 \mathrm{~m}$, the content of $\mathrm{U}$ is $0.02 \%$, Th is $0.12 \%$, Th/ $\mathrm{U} \sim 6$. The total length of Severnaya I ore deposit is more than $5 \mathrm{~km}$ [10].

The Severnoye mineralization was discovered in 1962 by N'yaskaya PSP and was considered as a detailed area Turman Severny [6]. The ore deposit Tsentralnaya I was established in this area and studied to a depth of $350 \mathrm{~m}$ by exploratory wells drilled at a pitch of 50-100 m. The deposit is associated with a trough-like structure formed at the intersection of deep faults of the sublatitudinal, northwestern and submeridional orientations at the place of sharp rotation of the structural and stratigraphic unconformity zone from the northwest to the sublatitudinal direction.

The size of this structure is $500 \mathrm{~m}$ in width, about $2 \mathrm{~km}$ in length north to its intersection by a deep fault of the northwest orientation and subvolcanic intrusion of gabbrodolerites. The deposit is outlined and localized at the base of thick (up to $120 \mathrm{~m}$ ) terrigenous stratum of the Hobeinskaya suite. Its dip is at angles of $40^{\circ}-50^{\circ}$ to the northeast, according to the tectonically rejuvenated contact of granites and the surface of the structural and stratigraphic unconformity. The thickness of the ore deposit varies from 22.7 to $18.7 \mathrm{~m}$ with an average content of $\mathrm{U}-0.013-0.044 \%$, Th $-0.068-0.14 \%$ with a thickness of ore intervals of 2.2 to 


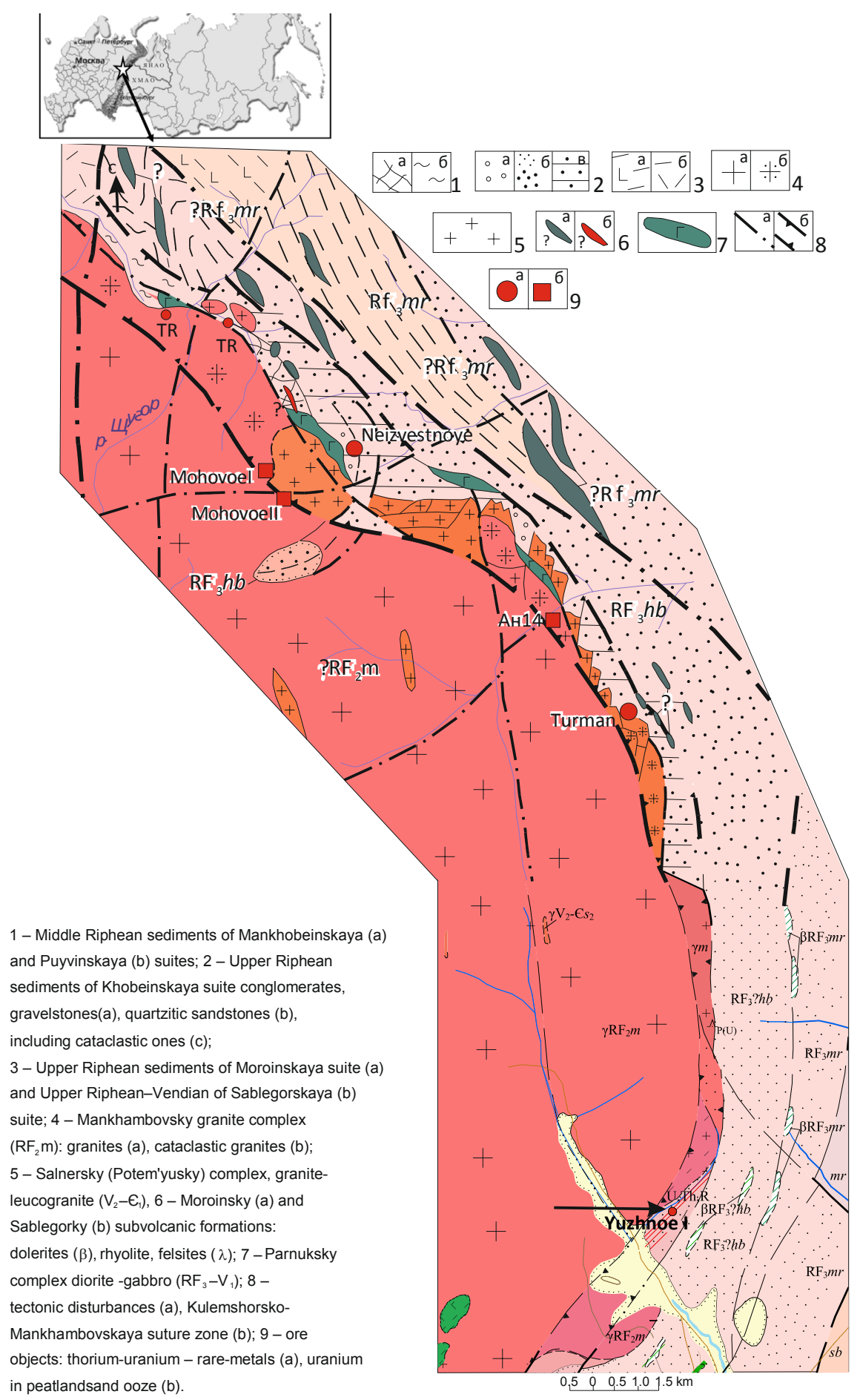

Figure 4. Geological map of the eastern frame of the Mankhambo massif (prepared by V. A. Dushin). Рисунок 4. Геологическая карта восточного обрамления массива Маньхамбо (составил В. А. Душин).

$7.7 \mathrm{~m}$. Separate ore intervals and ore deposits are generally associated with numerous bedded zones of cataclasis, brecciation, and fracturing in gravelly quartzite sandstones. These intervals, as a rule, are enriched with cataclased crushed debris of bluish-gray quartz. Some thin veins of potassium feldspar, green muscovite, fluorite, and ore (ilmenite, hematite, titanomagnetite) are localized on the fissures in the zones of the cataclasis and around the crushed debris. The ore deposit is outlined by a dip of $400 \mathrm{~m}$ (to a depth of $300 \mathrm{~m}$ ) and is not delineated. The mineralization productivity with depth significantly increases including $U$ from 0.0295 to $0.0823 \mathrm{~m}$.

The central part of the Mankhambovskaya ore zone is the mineralizations of Turman, Yuzhnoye and Yuzhnoye I (Fig. 4).

The Turman mineralization is on the watershed of the Par'ya river - the Gorely stream, on the eastern slope of the town of Par'ya $(555.5 \mathrm{~m})$. It was opened in 1960 by Hulginskaya aero-geological expedition. When carrying out some prognostic and exploration works in 2006-2009, two sections of detail - Turman Tsentralny and Turman Yuzhny, which correspond to the ore deposits of Tsentralnaya II and Yuzhnaya $[6,10]$. 
Table 4. Geochemical spectrum of ore occurrences of Neizvestnoye, Yuzhnoye (ICP MS, ppm). Таблица 4. Геохимический спектр руд проявлений Неизвестное, Южное (ICP MS, r/T).

\begin{tabular}{|c|c|c|c|c|c|c|c|}
\hline Element & Neizvestnoye & Yuzhnoye & Ukyu & Element & Neizvestnoye & Yuzhnoye & Ukyu \\
\hline $\mathrm{Li}$ & 32.4 & 1.9 & 1.2 & $\mathrm{Te}$ & 12.2 & 5.6 & 0.0 \\
\hline $\mathrm{Be}$ & 2.3 & 0.7 & 1.0 & 1 & 1.2 & 0.8 & \\
\hline Sc & 32.2 & 21.4 & 3.7 & Cs & 3.2 & 3.2 & 1.1 \\
\hline $\mathrm{Ti}$ & 9408.6 & 6315.1 & 1797.0 & $\mathrm{Ba}$ & 224.6 & 678.3 & 196.4 \\
\hline V & 65.1 & 15.1 & 13.9 & $\mathrm{Hf}$ & 343.4 & 192.0 & 30.3 \\
\hline $\mathrm{Cr}$ & 41.1 & 10.8 & 13.5 & Ta & 185.3 & 141.5 & 18.6 \\
\hline $\mathrm{Mn}$ & 482.7 & 1116.6 & 88.8 & W & 8.3 & 8.7 & 3.2 \\
\hline $\mathrm{Ni}$ & 27.1 & 10.1 & 4.8 & $\mathrm{Hg}$ & 0.4 & 0.4 & \\
\hline Co & 9.7 & 2.0 & 1.1 & $\operatorname{Re}$ & 0.4 & 0.2 & 0.0 \\
\hline $\mathrm{Cu}$ & 15.4 & 441.5 & 205.3 & $\mathrm{TI}$ & 0.3 & 0.1 & 0.2 \\
\hline $\mathrm{Bi}$ & 180.4 & 6.6 & 0.5 & $\mathrm{~Pb}$ & 280.0 & 271.5 & 9.7 \\
\hline $\mathrm{Zn}$ & 61.8 & 29.3 & 7.1 & $U$ & 1225.2 & 854.1 & 60.7 \\
\hline $\mathrm{Ga}$ & 8.1 & 19.9 & 7.8 & La & 1872.5 & 1623.9 & 57.0 \\
\hline $\mathrm{Ge}$ & 19.1 & 8.9 & 1.2 & $\mathrm{Ce}$ & 4620.7 & 2894.8 & 68.2 \\
\hline As & 0.6 & 1.2 & 1.2 & $\operatorname{Pr}$ & 317.7 & 288.2 & 9.5 \\
\hline $\mathrm{Rb}$ & 81.4 & 20.7 & 81.1 & $\mathrm{Nd}$ & 791.7 & 756.5 & 28.9 \\
\hline $\mathrm{Sr}$ & 161.5 & 243.2 & 11.6 & $\mathrm{Sm}$ & 108.2 & 122.5 & 7.0 \\
\hline$Y$ & 596.1 & 935.3 & 67.6 & $\mathrm{Eu}$ & 5.5 & 6.1 & 1.0 \\
\hline $\mathrm{Zr}$ & 7505.6 & 4855.2 & 434.5 & $\mathrm{Gd}$ & 93.3 & 123.1 & 8.7 \\
\hline $\mathrm{Nb}$ & 2595.5 & 1961.1 & 157.1 & $\mathrm{~Tb}$ & 13.6 & 19.8 & 1.6 \\
\hline Mo & 23.4 & 2.7 & 0.2 & Dy & 70.6 & 109.2 & 11.7 \\
\hline Th & 13079.0 & 9334.6 & 329.9 & $\mathrm{Ho}$ & 17.6 & 27.1 & 2.7 \\
\hline $\mathrm{Ag}$ & 135.5 & 2.5 & 3.6 & $\mathrm{Er}$ & 58.7 & 92.4 & 10.2 \\
\hline $\mathrm{Cd}$ & 10.9 & 3.9 & 0.02 & $\mathrm{Tm}$ & 13.3 & 16.6 & 1.9 \\
\hline In & 0.6 & 0.0 & & $\mathrm{Yb}$ & 104.7 & 122.3 & 15.6 \\
\hline Sn & 117.3 & 120.8 & 7.0 & Lu & 20.0 & 22.7 & 2.9 \\
\hline $\mathrm{Sb}$ & 1.1 & 0.3 & 0.1 & & & & \\
\hline
\end{tabular}

The ore deposit Tsentralnaya II is associated with the series of converged trough-like structures separated into some isolated blocks by a series of tectonic disturbances of the submeridional orientation. The deposit is localized in the lower part of the section of the ore-bearing strata, in conglomerate-breccias, gravelites, and gravelly quartzite sandstones. It has a medium pitch of $30^{\circ}-50^{\circ}$ to the northeast, concordant with the tectonically rejuvenated contact of granites and unconformity surface. The thickness varies from 3 to $15.9 \mathrm{~m}$, the average uranium content is $0.012-0.026 \%$, Th is $0.18-0.089 \%$ (at $\mathrm{Th} / \mathrm{U} 3.4-15$ ). In general, the Tsentralnaya-II ore deposit can be outlined for a distance of $4.5 \mathrm{~km}$. Distribution of mineralization along the vertical is about $200 \mathrm{~m}$.

The ore deposits Yuzhnaya is outlined by ditches and pits. The intensity of radioactivity in them varies from 50 to $2800 \mu \mathrm{R} / \mathrm{hr}$. The width of the ore intervals is from 1 to $30 \mathrm{~m}$. The deposit includes three uranium-thorium-ore bodies. Mineralization is usually located at the contact of gravelites and quartzite sandstones with granites and shale rocks, but is also noted in the middle and upper part of the section of the ore-hosting strata. Ores are bedded with thorite, uranium and thorium-containing ilmenorutile, zircon, tantaloniobates. The character of radioactivity is predominantly mixed, although lower values of $\mathrm{Th} / \mathrm{U}$ are noted (up to 1 or less).

The Yuzhnoye and Yuzhnoye I mineralizations are located in the upstreams of the Nyays and Mannyays rivers. The Yuzhnoye mineralization is located in the north of the section, in the valley of the left nameless tributary of the Nyays river, Yuzhnoye I - in the south, in the valley of the Mannyas river (Figure 4). When estimating the section in a $8.2 \mathrm{~km}$ long and a width of 2 to $9 \mathrm{~m}$, a series of thin lenses (from several centimeters to several meters) and vein-like bodies with rare metal mineralization (probably, vein stockwork?!) are established. They have length from $100 \mathrm{~m}$ to several kilometers separated by ore-free intervals. In the conglomerates (pseudoconglomerates), gravelites, and less frequently in quartzite sandstone, there is an impregnation of thorite, orthite, uranotorite, hatchettolite, uranium-containing zircon, titanic iron ore, ilmenorutil, magnetite, titanomagnetite and secondary minerals: otenite, uranocircite, limonite, associated with the base of the section. In this case, the tectonized contact with elements of weathering crust is fixed here. Quartz-feldspar rocks contain sericite, muscovite, biotite, chlorite, apatite, sphen, tourmaline, epidote. According to the composition of elements, two types of mineralization are distinguished: uranium-thorium-zirconium and uranium-tantalum-niobium-rare earth. In the quartz-bearing, faulted and folded schists, there is a rich vein orthite mineralization. The $\mathrm{U}$ content is $0.03-0.32 \%$, Th is $0.11-4.4 \%$ (chemical analysis). The secular equilibrium coefficient is from 75 to $131 \%$. In the technological sample, the content, \%: $\mathrm{U}-0.36, \mathrm{Th}-4.9, \mathrm{Ta}_{2} \mathrm{O}_{5}-0.03, \mathrm{Nb}_{2} \mathrm{O}_{5}-0.3, \mathrm{ZrO}_{2}-0.96, \Sigma \mathrm{TR}_{2} \mathrm{O}_{3}$ - 3.95. Two midge wells were drilled in the north of the Yuzhnoye mineralization, which blocked out the ore zone up to $5 \mathrm{~m}$ in thickness at a depth of $50 \mathrm{~m}$. It is represented by a series of ore veins up to $5-8 \mathrm{~mm}$ in thickness and veinlet-impregnated ore in a cement of conglomerates with gamma ray logging up to $6,000 \mu \mathrm{R} / \mathrm{hr}$. The exploring shaft of a large section laid here, has been passed to a depth of $7 \mathrm{~m}$. Quartzites with thin beddings of quartz gravels characterized by radioactivity up to several thousand $\mu \mathrm{R} /$ $\mathrm{hr}$, have been opened in the broken ground interval with the exploring shaft. Three samples from an interval of 1 to $5 \mathrm{~m}$, mainly in gravelite quartzites, are characterized by the following content of useful components, \%: $\mathrm{U}$ is $0.01-0.04$, Th is $0.08-0.46, \Sigma \mathrm{TR}_{2} \mathrm{O}_{3}$ 
is $0.1-0.59, \mathrm{Ta}_{2} \mathrm{O}_{5}$ is $0.002-0.008, \mathrm{Nb}_{2} \mathrm{O}_{5}$ is $0.013-0.015, \mathrm{ZrO}_{2}-0.081-0.29$. At the same time, the content of ore elements increases with depth.

The content of rare and radioactive elements in the Yuzhnoye ore mineralization is shown in Table 4. Its analysis shows that the distribution of the concentrations of trace elements in the ores of the Yuzhnoye mineralization differs in their increased contents with respect to the Yukyu mineralization and is similar to the Neizvestnoye mineralization. As a rule, the content of rare-earth elements increases with an increase in the degree of metasomatic alterations in rocks. A significant shortage of heavy elements is typical - in metasomatites, the ratio $\mathrm{La} / \mathrm{Yb}=8.65-8.96$, and it does not exceed 2.90 in granites of the basement.

The correlation analysis showed a strong connection between radioactive and rare elements in ores, as well as a weak but significant dependence of titanium oxide and rare earths. Obviously, the genetic relationship with titanium is poorly expressed in the rare earths of the yttrium group $(r=0.34)$. The content of $\mathrm{U}, \mathrm{Th}, \mathrm{TR}, \mathrm{Ta}, \mathrm{Nb}$ in ores is directly proportional and simultaneously increases or decreases. The ores have their constant multicomponent features.

The mineralization of Khapharthuytum was found in 1963 and is located $2.5 \mathrm{~km}$ to the north-west of Yana-Khaphartuytum (Fig. 2). The section of mineralization is located in the southeastern exocontact of the Mankhambo granite massif and is stroked by a narrow band in the meridional direction for $4.5 \mathrm{~km}$. It has sedimentary-metamorphic rocks of the Hobeinskaya suite intruded by small-sized stock-like intrusions of microcline medium- and fine-grained granites of the Salnersky complex and dykes of the Moroinsky amphibolized gabbrodolerites. The rocks as a whole have a heavy eastern monoclinal dip and have folds complicated by disjunctive faults of the meridional and sublatitudinal directions. In conglomerates and quartzites, poor mineralization is noted. Along the strike, the mineralization is outlined for $1.5 \mathrm{~km}$, the thickness of the zone is $20-30$ m. Radioactivity of mineralized rocks in the range of $40-70 \mu \mathrm{R} / \mathrm{hr}$, at occasional points $-160 \mu \mathrm{R} / \mathrm{hr}$. The character of the anomalies is uranium-thorium one. Content of useful components, \%: $\mathrm{U}$ is $0.005-0.018$, Th is $0.006-0.074, \Sigma \mathrm{TR}_{2} \mathrm{O}_{3}$ is $0.005-0.19, \mathrm{Ta}_{2} \mathrm{O}_{5}$ is $0.003-0.005, \mathrm{Nb}_{2} \mathrm{O}_{5}$ is $0.005-0.1, \mathrm{ZrO}_{2}$ is up to 0.24 . The content of silver in conglomerates is up to $6.1 \mathrm{ppm}$. The main minerals-carriers of tantalum and niobium are ilmenite and rutile; rare earths are found mainly in the orthite, which has intergrowth with titanic iron ore, zircon, muscovite and sometimes quartz. Uranium and thorium, most likely, are present in the form of isomorphic impurities in ilmenorutils, titanic iron ore, and zircons.

Mineralization of Ukyu is located on the left and right slopes of the valley of the Ukyu river striking to the north and south of the Man-Khaphartuytump peak, and opened in 1963 (Fig. 2). It is associated with the Kulemshorsko-Mankhambovskaya zone and is located in the southern far exocontact of the Manhambo granite massif among the quartzite strata with beddings of gravelites and conglomerates belonging to the Hobeinskaya suite of the upper Riphean. The strike of rocks is submeridional, east dip at 10-65. Folded structures are complicated by disjunctive faults; ore mineralization characterized by radioactivity of $60-250 \mu R / h r$ is observed along the planes of schistosity; and up to $1150 \mu \mathrm{R} / \mathrm{hr}$ at some points The ore-bearing zone is outlined along the strike by $7.3 \mathrm{~km}$ with a width of $100 \mathrm{~m}$ in the north and to $50 \mathrm{~m}$ in the south. The ores are characterized by a high content of Ta, $\mathrm{Nb}$, $\mathrm{TR}, \mathrm{Zr}, \mathrm{U}$ and Th. Concentration, \%: $\mathrm{U}$ is up to 0.019 , Th is up to $0.18, \mathrm{Ta}_{2} \mathrm{O}_{5}$ is $0.002-0.01, \mathrm{Nb}_{2} \mathrm{O}_{5}$ is $0.017-0.11, \mathrm{ZrO}$ is $0.05-0.3$, $\Sigma \mathrm{TR}_{2} \mathrm{O}_{3}-0.19-0.43$. Mineralization along the strike of the ore zone is distributed unevenly.

Ore minerals: ilmenite, hematite, ilmenorutile, zircon, ortite, thorite, magnetite, titanomagnetite, leucoxene, rutile, hatchettolite, autunite, etc. Non-metallic mineral: feldspars, quartz, mica, apatite, sphen, tourmaline, garnet, epidote, chlorite, etc. The amount of ore minerals varies in wide ranges - from grams to kilograms per ton; for titanic iron ore - to hundreds of kilograms. The content of ore components in the Ukyu mineralization, according to ICP MS, is shown in Table 4. The ores are distinguished by a close correlation between $\mathrm{Y}$ and $\mathrm{Ti}(r=0.79)$, but the correlation coefficient between Ce and Ti is -0.13 , which indicates that there is no correlation between these elements. It can be assumed that the minerals of titanium and iron contain yttrium in their composition, as well as elements of rare earths of yttrium and cerium groups. During the GDP-200/2, while test operation works in the Right Ukyu-Left Ukyu watershed in the same zone, we have established two more points of mineralization [6]. In the first of them, a halo of increased radioactivity (above $30 \mu \mathrm{R} / \mathrm{hr}$ ) with dimensions of $500 \times 300 \mathrm{~m}$ was recorded in the eluvial sediments of quartzite sandstones with large blocks. Within the halo, 5 local maxima with values of 65, 70, 72, 80 and $150 \mu \mathrm{R} / \mathrm{hr}$ have been identified at a distance of 60-100 m from each other. The maxima are associated with thin (10-15 mm) beddings enriched with a black ore mineral. The highest radioactivity $(150 \mu \mathrm{R} / \mathrm{hr})$ is connected to quartzite sandstones. There are some elements established by the rock chip sampling, ppm: U - 61, Th - 330, $\Sigma \mathrm{TR}-230, \mathrm{Zr}-435, \mathrm{Nb}-157, \mathrm{Ta}-19, \mathrm{Ag}-4, \mathrm{Pt}-0,4$ (ICP-MS). The spectral analysis has shown, ppm: $\mathrm{Ce}-200, \mathrm{Y}-30, \mathrm{Yb}-3, \mathrm{Nb}-60, \mathrm{Zr}-150$. The second point of mineralization is also recorded in the sediments of gneisses of quartz-feldspar-biotite composition. One of the blocks contains impregnation of the black ore mineral in the form of a run about $30 \mathrm{~cm}$ wide, to which high radioactivity is associated - 300-500 $\mu \mathrm{R} / \mathrm{hr}$ against the background of 3040. The following elements are established in the sample from this block, ppm: $\mathrm{U}-82, \mathrm{Th}-547, \Sigma \mathrm{TR}-151, \mathrm{Zr}-348, \mathrm{Nb}-150$, $\mathrm{Ta}-18, \mathrm{Ag}-3$, Pt - 0,3 (ICP-MS).

Uranium beresite formation in the volcanic rocks is represented by several objects in the ore mineralizations. This is a large mineralization of Redka I and a number of smaller ones Redka II, Leptaizskoye, Podcheremskoye, Telposskoye, accompanied by a large number of mineralization points and radioactive anomalies that are developed both in the northern part of the Kulemshorsko-Mankhambovskaya zone and in the southern part. All of them are due to the occurence of trachyriolites and rhyolites of the Sablegorskaya, Laptopayskaya and Bolshepatokskaya subvolcanic complexes (Fig. 2).

The Redka I mineralization is located in the southeastern slope of the mountain of the same name (the source of the Podcherem river) and was found during the wide-scale searches in 1964 by Ponyinskaya and Vorkutinskaya expedition [6]. It is associated with the Podcheremskaya Vendian-Early Cambrian paleo-volcanic structure of the central type injected with dolerite-trachyriolite magmatism of the Sablegorskaya-Laptopayskaya and Bolshepatokskaya complexes. The ore zone with a radioactivity of $45-125 \mu \mathrm{R} / \mathrm{hr}$ (with two maximum values of $700-2500 \mu \mathrm{R} / \mathrm{hr}$ ) is connected with the endocontact of schistose and ferruginized trachyriolites, which have a visible thickness of 350-400 m. The zone is outlined along the strike for $6.2 \mathrm{~km}$ in the north-west direction and dips to the south-west at $45^{\circ}-70^{\circ}$. In the eastern endocontact of the intrusion a whole series of converged schistose zones with a thickness of 5 to $30 \mathrm{~m}$ is established, along which the rocks are metasomatically transformed including hematitized, 
pyritized and carbonatized. The uranium content ranges from $0.03 \%$ to $3.4 \mathrm{~m}$; in the exposure of the Rudny stream to $0.075 \%$ for thickness of $0.45 \mathrm{~m}$, including $2.305 \%$ for thickness of $0.15 \mathrm{~m}$. There were found 14 uranium-bearing echelon-like veins with a length of 12 to $70 \mathrm{~m}$ at thickness of $0.5-5.5 \mathrm{~m}$ with uranium content of $0.031-0.054 \%$ and higher. Mineralization is represented by uranite, secondary minerals - curite and kazolite. Titanic iron ore, fluorapatite, titanite, manganoilmenite, zircon, orthite, monazite, magnetite, pyrite, hematite, chalcopyrite, galena, molybdenite, sphalerite, and wulfenite are also found in the ores. The most widespread are bornite, covellite, malachite, cerussite, gummite among secondary minerals. Based on the results of the semi-quantitative analysis, the following contents are established in ores, $\%$ : $\mathrm{Cu}-0,2, \mathrm{~Pb}-0,2, \mathrm{Ag}-0,001, \mathrm{Mo}-0,01, \mathrm{Nb}-0,007$, $\mathrm{Zr}-0,03, \mathrm{U}-0,1, \mathrm{Y}-0,01$. According to ICP MS, \%: $\mathrm{Cu}-0,3, \mathrm{~Pb}-0,04, \mathrm{Ag}-0,001, \mathrm{Mo}-0,008, \mathrm{Nb}-0,005, \mathrm{Zr}-0,05, \mathrm{U}-0,04$, $\Sigma T R-0,03$. The metasomatic core corresponds to the beresite formation, the calculation of its substance budget shows that the formation of polymetallic mineralization is associated with the stage of acid leaching in the outer zones, whereas the formation of uranium and rare metal mineralization occurred at the late alkaline stage in the interior zones of the core [2].

The southern part of the Kulemshorsko-Mankhambovskaya zone within the Matumskaya paleovolcanic structure is potentially promising for the uranium beresite ore formation, as evidenced by two radiometric anomalies, the concentrate stream of rare earth minerals, eight point lithochemical anomalies of rare metals. Some radioactive anomalies are identified in the valley of the Matum-Takhamtamya river. The rhyolites of the Laptopaysky complex here are distinguished by increased radioactivity (up to $30 \mu \mathrm{R} / \mathrm{hr}$ and more). Two anomalous zones with separate radioactivity points are established up to $224 \mu \mathrm{R} / \mathrm{hr}$. Anomalies are associated with zones of schistose, kaolinization, fluorsparization, and barytization. The thickness of anomalous intervals along the ditches is $0.2-1.0 \mathrm{~m}$, the length is the first meters. The content of $\mathrm{U}-0,012 \%$ in the crashed samples have been established barite, galena, pyrite, magnetite, ilmenite, hematite, rutile, zircon, leucoxene.

The development of modern infiltration concentrations of uranium in peat-mud deposits of surface watercourses (surface type according to the IAEA classification) is typical for the Mankhambovskaya area. These are the occurrences of Maldizskoye, Perchuk II, Perchuk I point of mineralization and a number of radioactive anomalies (Fig. 2, 4).

The occurrence of Maldizskoye was discovered by the Khulginsky airborne geophysical expedition of the Tyumen State University in 1962. It is located in the upstreams of the Pyrsyu river. The site of occurrence is near the zone of the northeastern fault with medium-grained, partially albitized granites, intruded by small bodies of leucocratic granites. The group of 12 point halos with a radioactivity of 100 to $700-1500 \mu \mathrm{R} / \mathrm{hr}$ associated with shallow watercourses was established in the occurrence. The length of the anomalous watercourses is $150-200 \mathrm{~m}$ at a width of up to $1.5 \mathrm{~m}$, rarely up to $10-15 \mathrm{~m}$. The highest radioactivity up to 880 $\mu \mathrm{R} / \mathrm{hr}$ has a water-out layer of loam soil with vegetable earth at a depth of $25-30 \mathrm{~cm}$. The content of $\mathrm{U}$ in the samples of weak material with vegetable earth is $0.03-0.092 \%$ according to the chemical analysis and $0.026 \%$ according to luminescent-pearl $[2,6]$.

The occurrence of Perchuk II is located in the valley of the Padel stream and represent a radioactive anomaly in groundwater similar to the Maldizskoye. The occurrence was open by the Ilychskaya airborne geophysical group of the Vorkutinskaya geological survey expedition in 1964. The section of occurrence has coarse-grained cataclasized two-mica granites. Granites have a cover of soft quaternary sediments represented by loams with fragments of granites. In the central part of the section, there is a tectonic disturbance of the submeridional strike in the form of mylonitization with a width of $6 \mathrm{~m}$. Peatlands are also developed here. Two radioactive haloes with dimensions of $100 \times 130$ and $50 \times 35 \mathrm{~m}$ with a radioactivity of up to $372 \mu \mathrm{R} / \mathrm{h}$ are established, which are associated with water from freshets in the area of their sources. The radon anomaly (no thoron) $300 \times 300 \mathrm{~m}$ is installed in water in size with a maximum concentration of $1392 \mathrm{Em}$. The content of $U$ in soft sediments is $0.005-0.16 \%$, according to the data of the radiation analysis, and $0.002-0.023 \%$ according to the luminescent-pearl analysis. It is also established, \%: Y - 0.005-1.0, Mo - 0.0005-0.003, $\mathrm{Zr}-0.005-0.02, \mathrm{~V}-0.001-0.01, \mathrm{~Pb}-0.0003, \mathrm{Ga}-0.0005-0.005, \mathrm{Cu}-0.001$ [6].

The Perchuk I point of mineralization is located in the south, in the sources of the Yidzhid-Parus-Yol stream and has similar characteristics.

S. S. Shcherbin described the anomaly called "Mokhovaya" located $2 \mathrm{~km}$ to the west of the Paryaur and Neizvestnoye occurrences, in the sources of the Lagerny stream (left tributary of the Parya river). Here some radioactive anomalies in mosses are fixed. In the samples from radioactive mosses, the anomalous content of $U$, Th, Mo, TR, Be is determined. In terms of dry matter, the $\mathrm{U}$ content was, \%: $0.01-0.61$, Th - up to $0.03, \Sigma \mathrm{TR}_{2} \mathrm{O}_{3}-0.05-0.86$ (Fig. 4). The analogous anomaly (No $14 \mathrm{G}[2,6]$ ) associated with the contact of granites and sandstones was established in the Turman Tsentralny section within the generalized contour [15]. The maximum width of the anomaly is $80 \mathrm{~m}$, the activity is up to $450 \mu \mathrm{R} / \mathrm{h}$. The gray-colored alluvial deposits with pebbles of various types - quartzite sandstones, shale rocks, and granites covered with peat-mud deposits up to $1 \mathrm{~m}$ thick. X-ray spectral analysis has shown the maximum content of $U-0.4913 \%$ with an insignificant content of Th - up to $0.0019 \%$ associated with peat-mud deposits. In gray-colored alluvial deposits, there is also a high content of $U-0.017 \%$ with Th concentration of 0.0012 $\%$. The average-weighted content of $U$ is $0.2337 \%$ for a thickness of $1.2 \mathrm{~m}$. The type of the anomaly is essentially uranium one. A peculiar "mossy" anomaly of radioactivity was established by us in the upstream of the Shchugor river (Mokhovoye II). The anomaly is outlined along the contour at $50 \mu \mathrm{R} / \mathrm{h}$ and has dimensions of $15 \times 30 \mathrm{~m}$ with an epicenter of $100 \mu \mathrm{R} / \mathrm{h}$ on the surface. The opening of the epicenter at a depth of $60 \mathrm{~cm}$ showed a radioactivity of about $1800 \mu \mathrm{R} / \mathrm{h}$, which was outlined along the contour of $1000 \mu \mathrm{R} / \mathrm{h}$ to a depth of $1.2 \mathrm{~m}$, to the permafrost level [6]. The black peat with a low-observable structure and characteristic odor has the highest radioactivity. It is placed of ordinary peat bogs on the surface in the system of water-sick watersheds and river drains. Such a point-nodal anomaly is probably associated with deep emanations from an endogenous stockwork-type source in the zone of the fault in the southern exocontact of the Atolyasyahal stock, which indicates very significant prospects for the Neizvestny-Paleodolinny section with respect to complex U-Th-TR mineralization.

Conclusion

Thus, the Mankhambovsky block is a structure close to formations of the middle massif or terrane type, the nuclear parts of which form the Doriphean?-Riphean conjugated in space, magmatogene-metamorphogenic crust-metasomatic ore systems, similar to the structural-material basement complexes of platforms for which the pre-Vendian metallogeny of the platform intraplate stage is typical (Fe-quartzites, pegmatites, skarns, coastal metamorphosed placers, (Fe, U, Th, TR, Au, Ag, Pd), as well as 
the collision Vendian-Early Cambrian albitite (greisen)-isite-beresite (U, Th Mo, Be, Au, TR, Cu), the Paleozoic rift-collisional qualmites-eisite-beresite ( $\mathrm{Ta}-\mathrm{Nb}, \mathrm{Be}, \mathrm{U}, \mathrm{Th})$ and Mesozoic-Cenozoic ( $\mathrm{Au}, \mathrm{U}$ ) intraplate type of "hot spots" of metallogeny of infiltration-argillicite nature. This circumstance determined the observed polygenicity (metamorphogenic-sedimentary, rare-metal-albitite-greisen, hydrothermal qualmite-eust-beresite, argillizite) and polychronism $\left(\mathrm{RF}_{2}-\mathrm{KZ}\right)$ of the iron-ore (MAN-9) rare metal-rare earth (Great Turupya, Yuzhnoye), uranium-thorium with gold and platinoid mineralization (Thurman, Neizvestnoye, Mokhovoe, etc.). The obtained data make it possible to assert that within the Mankhambovsky block it is possible to expect the discovery of medium-scale deposits of complex ores where the main components are rare earths, uranium, thorium, tantalum, niobium, zirconium, and associated gold, platinum, beryllium, possibly apatite, fluorite, etc.

\section{REFERENCES}

1. Dushin V. A. 1997, Magmatizm i geodinamika paleokontinental'nogo sektora severa Urala [Magmatism and geodynamics of the paleocontinental sector of the north of the Urals]. Moscow, 213 p.

2. Dushin V. A., Makarov A. B. 2017, Geologiya i poleznyye iskopayemyye Urala i Sibiri [Geology and minerals of the Urals and Siberia]: to the 95 anniversary of the Department of Geology, search, and exploration of mineral deposits. Ekaterinburg, $196 \mathrm{p}$.

3. Hamilton W. 1970, The Uralides and the motion of the Russian and Siberian platforms. GSA Bulletin. Vol. 81/(9), pp. 2553-2576.

4. Gee D. G., Pease V. L. (eds.). 2004, The Neoproterozoic Timanide Orogen of Eastern Baltica. London, Geological Society, Memoirs. 30, 1-3, 248 p.

5. Gee D. G., Bogolepova O. K., Lorenz H. 2006, The Timanide, Caledonide and Uralide orogens in the Eurasian high Arctic, and relationships to the paleo-continents Laurentia, Baltica and Siberia. London, Geological Society, Memoirs. 32, pp. 507-520.

6. Dushin V. A., Serdyukova O. P., Malyugin A. A. et al. 2017, State Geological Map of the Russian Federation. Scale $1: 200000.2^{\text {nd }}$ edition. Severo-Uralskaya Ser. Sheet P-40-XII (Kozhim-Iz). Explanatory note. Moscow, 263 p.

7. Pystina Yu. I., Pystin A. M. Tsirkonovaya letopis' ural'skogo dokembriya [Zircon chronicle of the Ural Precambrian]. Ekaterinburg, 2002.187 p. 8. Morozov A. F., Petrov O. V., Melgunov A. N. (eds.). 2010, Osnovnyye cherty geologicheskogo stroyeniya i mineral'no-syr'yevoy potentsial Severnogo, Pripolyarnogo i Polyarnogo Urala [The main features of the geological structure and the mineral and raw material potential of the Northern, Subpolar and Polar Urals]. Saint Petersburg, 274 p.

9. Shcherbin S. S. 1968, Geologicheskiye usloviya formirovaniya i lokalizatsii radioaktivno-redkometall'nogo orudeneniya $v$ drevnikh konglomeratakh [Geological conditions of formation and localization of radioactive-rare metal metallogenesis in ancient conglomerates]. In collection "Geology and genesis of endogenous uranium deposits". Moscow, pp. 50-67.

10. Mezenov I. A., Arkhangelskaya V. V., Dushin V. A. et al. 2008, Perspektivy promyshlennoy rudonosnosti kompleksnogo blagorodno-redkometall'no-uran-toriyevogo i uranovogo orudeneniya v Man'khambovskom uranonosnom rayone Pripolyarnogo Urala [Prospects of industrial ore content of complex noble-rare metal-uranium-thorium and uranium mineralization in the Manhambo uranium-bearing region of the Subpolar Urals]. Puti realizatsii neftegazovogo i rudnogo potentsiala Khanty-Mansiyskogo avtonomnogo okruga - Yugry [Ways of realizing the oil and gas and ore potential of the Khanty-Mansiysk Autonomous Okrug - Ugra]. Vol. 2. Khanty-Mansiysk, pp. 445-456.

11. Kalinovsky A. V. 1990, Redkometall'nyye kompleksy Man'khambovskogo metallogenicheskogo rayona na Severnom Urale [Rare metal complexes of the Mankhambovskiy metallogenic region in the Northern Urals]. Preprint. Syktyvkar, $23 \mathrm{p}$.

12. Udoratina O. V. 2000, Berilliyevonosnyye metasomatity Severnogo Urala [Beryllium-bearing metasomatites of the Northern Urals]. Metallogeny and geodynamics of the Urals: report III The Urals metallogenic meeting of the Ural branch of the Russian Academy of Sciences. Ekaterinburg, pp. $170-171$.

13. Udoratina O. V. et al. 2006, Vozrast granitoidov Man'khambovskogo i ll'yaizskogo massivov (Severnyy Ural): U-Pb dannyye [Age of granitoids of the Mankhambovsky and llyaiz massifs (Northern Urals): U-Pb data]. Doklady RAN [Reports of the Russian Academy of Sciences], vol. 406, no. 6 , pp. 810-815.

14. Kuznetsov N. B., Udoratina O. V. 2007, Geodinamicheskiye usloviya formirovaniya i vozrast granitoidov Vangyrskogo massiva, Pripolyarnyy Ural [Age and geotectonic position of Late Precambrian granitoids of Vangyr Massif, Subpolar Urals]. Bulleten' MOIP [Bulletin of the Moscow Society of Naturalists. Geological Series], vol. 82, no. 2, pp. 3-12.

15. Shcherbin S. S. 1974, Vzaimootnosheniye raznovozrastnykh granitoidov s doordovikskimi osadochno-metamorficheskimi porodami $v$ rayone Man'khambo na Pripolyarnom Urale [Relations of different-aged granitoids with pre-Ordovician sedimentary-metamorphic rocks in the Mankhambo region in the Subpolar Urals]. Magmatizm, metamorfizm i orudeneniye $v$ geologicheskoy istorii Urala [Magmatism, metamorphism and mineralization in the geological history of the Urals]. Sverdlovsk, pp. 62-64. 


\title{
Геология и полезные ископаемые Маньхамбовского блока (Приполярный Урал)
}

\author{
Владимир Александрович Душин, \\ Vladimir.Dushin@m.ursmu.ru \\ Денис Игоревич Прокопчук, \\ uva9090@mail.ru \\ Вениамин Сергеевич Козьмин, \\ Veniamin.Kozmin@m.ursmu.ru \\ Евгений Александрович Жуклин, \\ Zhuklin7@gmail.com \\ Артем Константинович Трутнев \\ tema.trutnev@yandex.ru
}

\author{
Уральский государственный горный университет \\ Россия, Екатеринбург
}

\begin{abstract}
Актуальность работы закиючается в том, что исследованиями последнего десятилетия, в том числе в связи с работами Северной научно-исследовательской геологической экспедиции (СНИГЭ) в рамках Государственной программы “Воспроизводство и использование природных ресурсов" на 2012-2020 гг., подтвержАается серьезная перспективность Маньхамбовского блока в отношении рудных полезных ископаемых. Рассматриваемая в статье территория охватывает горную, обнаженную часть Северного и Приполярного Урала от истоков р. Печоры на юге $о$ бассейна р. Маньи на севере и протягивается в меридиональном направлении почти на 300 км, административно входя в Ханты-Мансийский автономный округ - Югру и отчасти - в Республику Коми. Перспективность Маньхамбовского блока в отношении рудных полезных ископаемых подтверждается исследованиями последнего десятилетия, в том числе в связи с работами Северной научно-исследовательской геологической экспедиции (СНИГЭ). В пределах рассматриваемого района установлено более 50 рудопроявлений (проявлений) и около 200 пунктов минерализации руд черных, цветных, благородных, радиоактивных и редких метамов. Железорудные объекты развиты ограниченно и обусловлены проявлениями двух рудных формаций - железистых кварцитов и скарновой железорудной. Из цветных метамов широким распространением пользуется только медь, хотя сушественных концентраций ее не установлено, а другие метамы практически не проявлены, за искиючением убогой полиметамической минерамизации в березитизированных отложениях лаптопайской свиты. РяА реАких метамов, вкиючаюший ниобий, тантал, беримий, цирконий, а также редкоземельные элементы в комплексе с ураном и торием, широко развит в пределах Маньхамбовской структуры, причем ведушее значение в рудах имеют уран и торий. Рациоактивные элементы в ассоциации с торием, редкими и редкоземельными метамами - это ведушие полезные ископаемые Маньхамбов-
\end{abstract} ского блока. На сегодняшний день здесь установлено около 20 объектов различного масштаба.

Цель работы - выяснение перспектив Маньхамбовского блока на редкометамьно-уран-ториевое оруденение.

Результаты работы. По условиям образования и особенностям размещения уран-редкометамьной минерамизации вылелены три рудные формации: 1) урановая полигенная в зонах несогласия, мокамизованная в обрамлении массива Маньхамбо в терригенных породах основания хобеинской свиты $\left(\mathrm{RF}_{3} h b\right)$; 2) урановая березитовая - гилротермальная вулканогенная в риолитах саблегорской и лаптопайской свит рисея-венда; 3) ураноносных торсяников - современная экзогенная инфильтрационная во мхах, торсряниках и покровных суглинках. Полученные Аанные позволяют утвержАать, что в пределах Маньхамбовского блока можно ожидать обнаружение средних по масштабам месторожцений комплексных руд.

Киючевые слова: геология, черные, цветные, редкие метамлы, уран, торий, Приполярный Урах, структурно-формационная зона, Маньхамбовский блок, рудопроявления, изотопный возраст.

\section{ЛИТЕРАТУРА}

1. Душин В. А. Магматизм и геодинамика палеоконтинентального сектора севера Урала. М.: Недра, 1997. 213 с.

2. Душин В. А., Макаров А. Б. Геология и полезные ископаемые Урала и Сибири: к 95-летию кафедры геологии, поисков и разведки месторождений полезных ископаемых. Екатеринбург: Изд-во УГГУ, 2017. 196 с.

3. Hamilton W. The Uralides and the motion of the Russian and Siberian platforms // Geol. Soc. Amer. Bull. 1970. Vol. 81/(9). P. 2553-2576.

4. The Neoproterozoic Timanide Orogen of Eastern Baltica / D. G. Gee, V. L. Pease (eds.). London: Geological Society, Memoirs. 2004. Vol. 30. 248 p.

5. Gee D. G., Bogolepova O. K., Lorenz H. The Timanide, Caledonide and Uralide orogens in the Eurasian high Arctic, and relationships to the palaeo-continents Laurentia, Baltica and Siberia // European Lithosphere Dynamics: Geological Society Memoirs. 2006. Vol. 32. P. 507-520.

6. Душин В. А., Сердюкова О. П., Малюгин А. А. и др. Государственная геологическая карта Российской Федерации. Масштаб $1: 200$ 000. Изд. второе. Сер. Северо-Уральская. Лист Р-40-XII (г. Кожим-Из): пояснительная записка. М.: Московский филиал ФГБУ «ВСЕГЕИ», 2017. 263 c.

7. Пыстина Ю. И., Пыстин А. М. Цирконовая летопись уральского докембрия. Екатеринбург, 2002. 187 с.

8. Основные черты геологического строения и минерально-сырьевой потенциал Северного, Приполярного и Полярного Урала / ред. А. Ф. Морозов, О. В. Петров, А. Н. Мельгунов. СПб.: ВСЕГЕИ, 2010. 274 с.

9. Щербин С. С. Геологические условия формирования и локализации радиоактивно-редкометалльного оруденения в древних конгломератах // Геология и вопросы генезиса эндогенных урановых месторождений. М.: Наука, 1968. С. 50-67.

10. Мезенов И. А., Архангельская В. В., Душин В. А. и др. Перспективы промышленной рудоносности комплексного благородно-редкометалльно-уран-ториевого и уранового оруденения в Маньхамбовском ураноносном районе Приполярного Урала // Пути реализации нефтегазового и рудного потенциала Ханты-Мансийского автономного округа - Югры. Т. 2. Ханты-Мансийск: ИздатНаукаСервис, 2008. C. 445-456.

11. Калиновский А. В. Редкометалльные комплексы Маньхамбовского металлогенического района на Северном Урале. Препринт. Сыктывкар, 1990. 23 с.

12. Удоратина О. В. Бериллиевоносные метасоматиты Северного Урала // Металлогения и геодинамика Урала: тез. докл. III Всеурал. металлогенич. совещ. Екатеринбург: УрО РАН, МПР РФ, 2000. С. 170-171.

13. Возраст гранитоидов Маньхамбовского и Ильяизского массивов (Северный Урал): U-Pb данные / О. В. Удоратина и др. // ДАН. 2006. T. 406, № 6. C. 810-815.

14. Кузнецов Н. Б., Удоратина О. В. Геодинамические условия фрормирования и возраст гранитоидов Вангырского массива, Приполярный Урал // Бюл. МОИП. Отд. геологич. 2007. Т. 82. Вып. 2. С. 3-12.

15. Щербин С. С. Взаимоотношение разновозрастных гранитоидов с доордовикскими осадочно-метаморфическими породами в районе Маньхамбо на Приполярном Урале // Магматизм, метаморфизм и оруденение в геологической истории Урала. Свердловск, 1974. С. 62-64. 